\title{
Investigation and amelioration of long-term instrumental drifts in water vapor and nitrous oxide measurements from the Aura Microwave Limb Sounder (MLS) and their implications for studies of variability and trends
}

\author{
Nathaniel J. Livesey ${ }^{1}$, William G. Read ${ }^{1}$, Lucien Froidevaux ${ }^{1}$, Alyn Lambert ${ }^{1}$, Michelle L. Santee ${ }^{1}$, \\ Michael J. Schwartz ${ }^{1}$, Luis F. Millán ${ }^{1}$, Robert F. Jarnot ${ }^{1}$, Paul A. Wagner ${ }^{1}$, Dale F. Hurst ${ }^{2,3}$, Kaley A. Walker ${ }^{4}$, \\ Patrick E. Sheese ${ }^{4}$, and Gerald E. Nedoluha ${ }^{5}$ \\ ${ }^{1}$ Jet Propulsion Laboratory, California Institute of Technology, Pasadena, California, USA \\ ${ }^{2}$ Cooperative Institute for Research in Environmental Sciences, University of Colorado, Boulder, Colorado, USA \\ ${ }^{3}$ NOAA Global Monitoring Laboratory, Boulder, Colorado, USA \\ ${ }^{4}$ Department of Physics, University of Toronto, Ontario, Canada \\ ${ }^{5}$ Remote Sensing Division, Naval Research Laboratory, Washington, DC, USA
}

Correspondence: Nathaniel J. Livesey (nathaniel.j.livesey@jpl.nasa.gov)

Received: 26 May 2021 - Discussion started: 29 June 2021

Revised: 23 August 2021 - Accepted: 27 August 2021 - Published: 15 October 2021

\begin{abstract}
The Microwave Limb Sounder (MLS), launched on NASA's Aura spacecraft in 2004, measures vertical profiles of the abundances of key atmospheric species from the upper troposphere to the mesosphere with daily near-global coverage. We review the first 15 years of the record of $\mathrm{H}_{2} \mathrm{O}$ and $\mathrm{N}_{2} \mathrm{O}$ measurements from the MLS $190 \mathrm{GHz}$ subsystem (along with other $190 \mathrm{GHz}$ information), with a focus on their long-term stability, largely based on comparisons with measurements from other sensors. These comparisons generally show signs of an increasing drift in the MLS "version 4" (v4) $\mathrm{H}_{2} \mathrm{O}$ record starting around 2010. Specifically, comparisons with v4.1 measurements from the Atmospheric Chemistry Experiment Fourier Transform Spectrometer (ACE-FTS) indicate a $\sim 2 \%-3 \%$ per decade drift over much of the stratosphere, increasing to as much as $\sim 7 \%$ per decade around $46 \mathrm{hPa}$. Larger drifts, of around $7 \%-11 \%$ per decade, are seen in comparisons to balloon-borne frost point hygrometer measurements in the lower stratosphere. Microphysical calculations considering the formation of polar stratospheric clouds in the Antarctic winter stratosphere corroborate a drift in MLS v4 water vapor measurements in that region and season. In contrast, comparisons with the Sounding of the Atmosphere using Broadband Emission Radiometry (SABER) instrument on NASA's Thermosphere Iono-
\end{abstract}

sphere Mesosphere Energetics and Dynamics (TIMED) mission, and with ground-based Water Vapor Millimeter-wave Spectrometer (WVMS) instruments, do not show statistically significant drifts. However, the uncertainty in these comparisons is large enough to encompass most of the drifts identified in other comparisons. In parallel, the MLS $\mathrm{v} 4 \mathrm{~N}_{2} \mathrm{O}$ product is shown to be generally decreasing over the same period (when an increase in stratospheric $\mathrm{N}_{2} \mathrm{O}$ is expected, reflecting a secular growth in emissions), with a more pronounced drift in the lower stratosphere than that found for $\mathrm{H}_{2} \mathrm{O}$. Comparisons to ACE-FTS and to MLS $\mathrm{N}_{2} \mathrm{O}$ observations in a different spectral region, with the latter available from 2004 to 2013, indicate an altitude-dependent drift, growing from $5 \%$ per decade or less in the mid-stratosphere to as much as $15 \%$ per decade in the lower stratosphere. Detailed investigations of the behavior of the MLS $190 \mathrm{GHz}$ subsystem reveal a drift in its "sideband fraction" (the relative sensitivity of the $190 \mathrm{GHz}$ receiver to the two different parts of the microwave spectrum that it observes). Our studies indicate that sideband fraction drift accounts for much of the observed changes in the MLS $\mathrm{H}_{2} \mathrm{O}$ product and some portion of the changes seen in $\mathrm{N}_{2} \mathrm{O}$. The $190 \mathrm{GHz}$ sideband fraction drift has been corrected in the new "version 5" (v5) MLS algorithms, which have now been used to reprocess the entire MLS record. As 
a result of this correction, the MLS $v 5 \mathrm{H}_{2} \mathrm{O}$ record shows no statistically significant drifts compared to ACE-FTS. However, statistically significant drifts remain between MLS v5 and frost point measurements, although they are reduced. Drifts in v5 $\mathrm{N}_{2} \mathrm{O}$ are about half the size of those in $\mathrm{v} 4$ but remain statistically significant. Scientists are advised to use MLS v5 data in all future studies. Quantification of interregional and seasonal to annual changes in $\mathrm{MLS} \mathrm{H}_{2} \mathrm{O}$ and $\mathrm{N}_{2} \mathrm{O}$ will not be affected by the drift. However, caution is advised in studies using the MLS record to examine long-term (multiyear) variability and trends in either of these species, especially $\mathrm{N}_{2} \mathrm{O}$; such studies should only be undertaken in consultation with the MLS team. Importantly, this drift does not affect any of the MLS observations made in other spectral regions such as $\mathrm{O}_{3}, \mathrm{HCl}, \mathrm{CO}, \mathrm{ClO}$, or temperature.

\section{Introduction}

The Microwave Limb Sounder (MLS, Waters et al., 2006) is one of four instruments launched on NASA's Aura mission (Schoeberl et al., 2006) in July 2004 and has operated essentially continuously from launch to the present. The MLS GHz antenna looks in the "forward" direction from the Aura spacecraft and vertically scans Earth's limb from the surface to $\sim 95 \mathrm{~km}$ altitude every $\sim 26 \mathrm{~s}$, yielding $\sim 3500$ scans per day. Aura is in a near-polar $\left(98^{\circ}\right.$ inclined) sun-synchronous orbit, enabling MLS atmospheric observations from $82^{\circ} \mathrm{S}$ to $82^{\circ} \mathrm{N}$ each orbit. The instrument measures thermal microwave signals in the 118, 190, 240, 640, and $2500 \mathrm{GHz}$ regions of the spectrum, with separate microwave receiver and spectrometer assemblies for each region (two each for the 118 and $2500 \mathrm{GHz}$ regions, and one for each of the others, for a total of seven receivers). From these radiance measurements, the "Level 2" retrieval algorithms (Livesey et al., 2006; Read et al., 2006; Schwartz et al., 2006) deduce vertical abundance profiles of $\mathrm{O}_{3}, \mathrm{H}_{2} \mathrm{O}$, $\mathrm{N}_{2} \mathrm{O}, \mathrm{CO}, \mathrm{HNO}_{3}, \mathrm{HCl}, \mathrm{ClO}, \mathrm{HOCl}, \mathrm{CH}_{3} \mathrm{Cl}, \mathrm{BrO}, \mathrm{OH}, \mathrm{HO}_{2}$, $\mathrm{HCN}, \mathrm{CH}_{3} \mathrm{CN}, \mathrm{CH}_{3} \mathrm{OH}$, and $\mathrm{SO}_{2}$, along with temperature, geopotential height, cloud ice amount, and relative humidity.

With the Aura MLS data record now more than 17 years long (MLS having far exceeded its 5-year design life), many studies are employing it, sometimes in conjunction with other observational datasets, to characterize long-term atmospheric variability. Published investigations include the quantification of stratospheric ozone trends and their potential attribution to ozone layer recovery (e.g., Steinbrecht et al., 2017; Strahan and Douglass, 2018; Ball et al., 2018, 2019; Chipperfield et al., 2018; Petropavlovskikh et al., 2019), examination of trends in tropospheric ozone (e.g., Gaudel et al., 2018), and studies of long-term variability in stratospheric water vapor (e.g., Lossow et al., 2018) and longlived tracers and halogenated gases (e.g., Stolarski et al., 2018; Froidevaux et al., 2019). The MLS-observed interan- nual and long-term variability in trace gases has, in turn, been used to examine associated underlying variability in transport into, within, and out of the stratosphere (e.g., Dessler et al., 2014; Neu et al., 2014; Verstraeten et al., 2015; Han et al., 2019; Diallo et al., 2019; Ruiz et al., 2021). Accordingly, increased attention is being paid to the long-term stability of the MLS record, to ensure that all such studies are placed on a sound footing. In the case of the MLS ozone "standard" product (obtained from radiance measurements by the MLS $240 \mathrm{GHz}$ receiver), stability has previously been demonstrated through comparisons with ground-based lidar observations (Nair et al., 2012), and comparisons versus MLS data have been used as a measure of the stability of other longterm records (e.g., Adams et al., 2014; Eckert et al., 2014). Confidence in the stability of MLS ozone was further underscored in a very thorough study (Hubert et al., 2016) comparing ozone profiles from MLS and a range of other spaceborne sensors to a comprehensive set of coincident measurements from both ozone sondes and ground-based lidar. The authors concluded that the MLS "version 3" ozone record (at least through the May 2013 date then considered) was stable to within $\pm 1.5 \%$ per decade in the middle stratosphere and $\pm 2 \%$ per decade in the upper stratosphere, with these small drifts with respect to the lidar and sonde records not being statistically significant at $95 \%$. Larger and statistically significant drifts compared with the lidar and sonde records were seen at lower altitudes, although they were all within $\pm 5 \%$ per decade.

In contrast to ozone, we now have strong evidence that the MLS $\mathrm{H}_{2} \mathrm{O}$ and $\mathrm{N}_{2} \mathrm{O}$ products in "version 4" (v4), both measured by the $190 \mathrm{GHz}$ receiver, show larger and statistically significant drifts. This paper quantifies drifts in these and other species measured by the MLS $190 \mathrm{GHz}$ receiver, discusses factors that may be giving rise to the drifts, describes efforts by the MLS team to ameliorate those factors, and provides updated guidance to users of the affected MLS products. These drifts were first noted by Hurst et al. (2016) in comparisons of $\mathrm{MLS} \mathrm{H}_{2} \mathrm{O}$ with measurements from balloonborne NOAA frost point hygrometer (FPH) and cryogenic frost point hygrometer (CFH) instruments launched from Boulder (Colorado) and other locations. The Boulder comparisons show indications of an approximately $+10 \%$ per decade drift in MLS lower-stratospheric water vapor starting around 2009/2010. Section 2 revisits these findings and discusses further analyses and comparisons with other sensors that also show evidence for a positive drift in $\mathrm{MLS}_{2} \mathrm{O}$, albeit a slower one than that indicated by the frost point record. Section 2 also quantifies a drift between the MLS standard ozone product, measured at $240 \mathrm{GHz}$, and a diagnostic ozone product derived from an ozone line measured by the MLS $190 \mathrm{GHz}$ receiver. Section 2 finishes by examining MLS $\mathrm{N}_{2} \mathrm{O}$ measurements, which are drifting to smaller values. Section 3 provides background on the MLS $190 \mathrm{GHz}$ subsystem and its measurements and describes insights obtained into the probable underlying contributors to the observed drifts. Sec- 
tion 3 also details how, in the new MLS "version 5" (v5) data record, much of the $\mathrm{H}_{2} \mathrm{O}$ drift has been ameliorated, and drifts in $\mathrm{N}_{2} \mathrm{O}$ and $190 \mathrm{GHz} \mathrm{O}$ have been reduced. Finally, Sect. 4 provides a summary and, most importantly, guidance for users of the MLS $\mathrm{H}_{2} \mathrm{O}$ and $\mathrm{N}_{2} \mathrm{O}$ datasets as to how the drifts should be factored into future studies using those data.

\section{Observations and comparisons}

This section examines observed drifts in the $\mathrm{MLS}_{2} \mathrm{O}, \mathrm{N}_{2} \mathrm{O}$, and $190 \mathrm{GHz} \mathrm{O} 3$ products. MLS $190 \mathrm{GHz}$ signals are also the source of the MLS HCN product and contribute to the $\mathrm{HNO}_{3}$ product. However, the behavior of the latter two species is better considered as part of the discussion of the origin of the drifts in the first three products. Accordingly, consideration of the MLS $\mathrm{HCN}$ and $\mathrm{HNO}_{3}$ products is deferred to Sect. 3 .

\subsection{MLS water vapor observations}

\subsubsection{Comparisons with the balloon-borne hygrometer record}

In contrast with the lower and middle troposphere, for which a wealth of well-characterized observations exist to validate spaceborne humidity sensors, correlative observations of water vapor are far less frequent and sparser in the upper troposphere and lower stratosphere. Although both operational radiosondes and spaceborne Global Navigation Satellite System radio occultation sounders are able to profile temperature well into the stratosphere, neither provide scientifically useful water vapor information in or above the upper troposphere. We note that several in situ instruments have obtained lower-stratospheric water vapor observations from high-altitude aircraft, and these observations have been used for validation of the MLS water vapor product (e.g., Read et al., 2008; Weinstock et al., 2009). However, their campaign-based sampling is extremely sparse both temporally and spatially, severely hampering their application to validation of long-term variability in global spaceborne observations.

The longest near-continuous systematic record of in situ stratospheric water vapor observations comes from balloonborne frost point hygrometer instruments (Mastenbrook and Oltmans, 1983; Vömel et al., 2007, 2016; Hall et al., 2016; Hurst et al., 2011, 2014, 2016) launched from Boulder, Colorado. Additional frost point instruments have been routinely launched from a small number of locations, although not for as long a period. The typical uncertainty on frost point measurements of water vapor mixing ratios in the lower stratosphere is better than $6 \%$ (Hall et al., 2016; Vömel et al., 2016). Most of this uncertainty is in the form of "random" error due to oscillations in the feedback loop that maintains a stable layer of frost on a temperature-controlled mirror. Absolute accuracy is estimated to be significantly better. Specifically, through the careful calibration of each instrument,
$<0.05 \mathrm{~K}$ inaccuracies in frost point temperatures result in systematic errors of $<1 \%$ in stratospheric water vapor partial pressures. However, biases in radiosonde pressure measurements can increase mixing ratio biases to $4 \%$ or greater in the stratosphere (Hall et al., 2016).

Frost point sonde observations have underpinned the validation of stratospheric water vapor measurements from the MLS instruments (Vömel et al., 2007; Read et al., 2007) and other spaceborne sensors. As reported by Hurst et al. (2016), comparisons between the frost point record and MLS v4 $\mathrm{H}_{2} \mathrm{O}$ indicate a divergence between these two water vapor datasets in the lower stratosphere, commencing around 2010, with the MLS values increasing relative to the frost point record. Figure 1 presents an update of the Hurst et al. (2016) comparisons between MLS v4 and frost point measurements at Lauder (New Zealand), Hilo (Hawaii, USA), and Boulder (Colorado, USA). These time series have been extended with additional years and are shown with the sign convention switched compared with those presented by Hurst et al. (2016), in order to be consistent with later figures in this paper. As with the original study, the MLS and frost point data are quality screened using established rules described in Livesey et al. (2020) and Hurst et al. (2016), respectively, and the frost point profiles have been smoothed by the MLS "least squares operator" and averaging kernel.

The year 2010 was chosen as the starting point for the fitted drift in light of the findings of the Hurst et al. (2016) study, substantiated by the observed behavior of the MLS $190 \mathrm{GHz}$ receiver subsystem as discussed in Sect. 3. These and most other fits described in this paper are simple linear regressions of differences between individual MLS Level 2 profiles and coincident measurements. All differences carry equal weight in the regression (i.e., estimated precision and other factors are not accounted for). The strongest drifts, of $\sim 11 \%$ per decade, are seen in the $68 \mathrm{hPa}$ comparisons for all three sites, with the Lauder and Boulder drifts having $\sim \pm 3 \%$ per decade confidence and the Hilo drift being less definitive, although still clearly statistically significant, with a confidence interval of $\sim \pm 7 \%$ per decade. All three locations indicate a slower drift at $100 \mathrm{hPa}$ than at the higher altitudes, particularly Hilo, for which the $22 \mathrm{hPa}$ drift is also smaller than that at 68 and $46 \mathrm{hPa}$.

Except where noted otherwise, all of the statistical fits in this paper establish significance at $95 \%$ using a block bootstrap resampling of the fit residuals (e.g., Froidevaux et al., 2019 , and references therein) that uses 1-year blocks and allows for block replacement. For succinctness, rather than referring to the possibly asymmetric $95 \%$ confidence intervals from this analysis (which would require two numbers to describe), we will use $\pm 2 \sigma$ bounds to describe uncertainty in drifts, where the standard deviations, $\sigma$, are those resulting from the bootstrapping analysis. The differences between the $2 \sigma$ and the $2.5 \%$ and $97.5 \%$ thresholds are small in the cases shown here. 


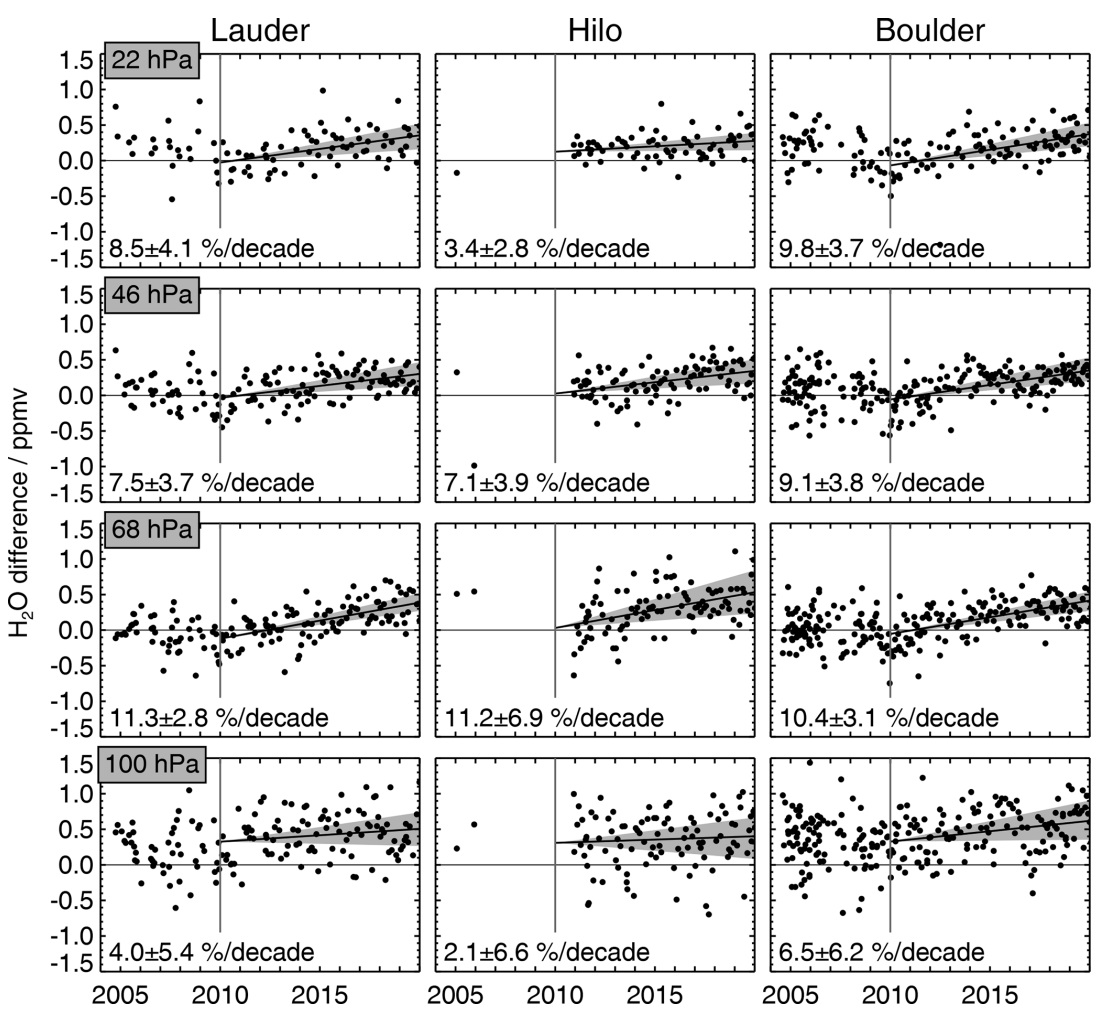

Figure 1. Time series of differences between MLS v4 water vapor and coincident frost point sonde measurements made from Lauder $\left(45^{\circ} \mathrm{S}\right.$, $170^{\circ} \mathrm{E}$, left), Hilo $\left(20^{\circ} \mathrm{N}, 155^{\circ} \mathrm{W}\right.$, center $)$, and Boulder $\left(40^{\circ} \mathrm{N}, 105^{\circ} \mathrm{W}\right.$, right) at selected pressure levels (rows). Coincidence criteria are, as in Hurst et al. (2016), $\pm 2^{\circ}$ latitude, $\pm 8^{\circ}$ longitude, and $\pm 18 \mathrm{~h}$. Positive differences imply that MLS measures greater humidity than the in situ observation. Black lines show a linear fit to the post-2010 differences (with all points weighted equally). Gray shading shows the $95 \%$ confidence interval for the slope (from a block bootstrap resampling of year-long blocks of the fit residuals). Fitted drift rates are quoted in each panel, with uncertainties corresponding to the $2 \sigma$ spread of the bootstrap results. Comparisons at the intermediate vertical levels (not shown) indicate similar behavior.

Given that each frost point sonde is an independently calibrated instrument and that the calibration scheme is referenced back to National Institute of Standards and Technology (NIST) standard temperature sensors as well as to a small archive of previously calibrated mirror thermistors, it seems unlikely that this drift reflects any systematic evolution of the calibration of the frost point sonde record. That said, we note the findings of Lossow et al. (2018), particularly their Fig. 8, which shows two multiyear periods during 19872001 when the frost point record at Boulder departed by $5 \%-10 \%$ from both model-based and satellite-based measures of stratospheric water vapor. We believe that these 2and 4-year periods of disparity may have resulted from atypically large, batch-dependent biases in radiosonde pressure sensors that propagated directly to the frost point mixing ratios. Such pressure biases became easily correctable after Global Positioning System (GPS) receivers were added to radiosondes after 2001, and similar disparities were not observed again until $\sim 2010$, when MLS water vapor retrievals began to drift.

\subsubsection{Comparisons with other spaceborne sensors}

Another source of near-continuous long-term stratospheric water vapor observations is the spaceborne Atmospheric Chemistry Experiment Fourier Transform Spectrometer (ACE-FTS) on the Canadian SCISAT-1 spacecraft, launched in 2003. ACE-FTS observes in a solar occultation geometry, providing vertical profiles of water vapor (and $\mathrm{N}_{2} \mathrm{O}$ and many other trace gases) each spacecraft sunset and sunrise, giving $\sim 30$ profiles of each measured species per day (Bernath et al., 2005). The SCISAT-1 orbit was chosen to preferentially cover high latitudes, limiting the occasions on which tropical and midlatitude regions are sampled to six or so 1week periods per year. Figure 2 shows drift rates inferred from linear fits to MLS v4 and ACE-FTS version 4.1 water vapor observations within various latitude bands for 20052010 (upper) and 2010-2019 (lower). ACE-FTS observations were screened according to the approach described in Sheese et al. (2015), and profiles are considered coincident if they are within $\pm 1^{\circ}$ latitude, $\pm 8^{\circ}$ longitude, and $\pm 12 \mathrm{~h}$. Given the similarity of the MLS and ACE-FTS vertical resolution, no averaging kernels were applied in this comparison. 
The strongest post-2010 drifts between MLS v4 and ACEFTS water vapor are around $4 \%-7 \%$ per decade $( \pm 6 \%$ per decade), seen at the 68 and $56 \mathrm{hPa}$ levels in the midlatitudes. There are strong indications of a drift at these and other pressure levels in all the latitude regions shown, although it is not significant at $2 \sigma$ in the $20^{\circ} \mathrm{S}-20^{\circ} \mathrm{N}$ band at most levels. The extratropical post-2010 drifts show a minimum value at $46 \mathrm{hPa}$, above which a fairly uniformly (and typically significant) positive drift of around $2-3 \%$ per decade is found. We note that these drifts are mostly smaller than those seen in the frost point comparisons (Fig. 1), particularly at higher altitudes (e.g., $22 \mathrm{hPa}$ ). By contrast, the 2005-2010 period shows essentially no statistically significant drifts between MLS v4 and ACE-FTS (a few levels/latitudes have $>2 \sigma$ drifts, although no more than might be expected when using a $\sim 95 \%$ confidence criterion for each of $\sim 24$ levels over three latitude bands).

Recently, the team responsible for the Sounding of the Atmosphere using Broadband Emission Radiometry (SABER) instrument on the Thermosphere Ionosphere Mesosphere Energetics and Dynamics (TIMED) mission, launched in 2002, has started providing a water vapor product from the lower stratosphere to the thermosphere (Rong et al., 2019). These data are estimated to have $4 \%$ precision on an individual profile below $60 \mathrm{~km}$ and have been shown to agree with those from other sensors to within $\sim 20 \%$ or better. Figure 3 shows estimated drifts between MLS v4 and SABER version 2.07 water vapor using the same coincidence criteria as used for ACE-FTS in Fig. 2. In contrast with ACE-FTS and the frost point observations, comparisons between MLS v4 and SABER show no statistically significant drift except perhaps in a narrow region around $3 \mathrm{hPa}$, where a $2 \%-3 \%$ per decade drift is seen in the southern and tropical latitude bands (a similar but not statistically significant pattern is seen in the northern latitudes also). The $2 \sigma$ uncertainties on the estimated lower-stratospheric drifts are significantly larger than those for the corresponding ACE-FTS comparisons. In many cases, the $2 \sigma$ uncertainty in MLS versus SABER drift encompasses the drift estimated from the MLS and ACE-FTS comparisons.

\subsubsection{Comparisons with ground-based observations}

Water vapor in the upper stratosphere and lower mesosphere can be measured from the ground by zenith-viewing microwave spectrometers. Figure 4 compares observations of water vapor at around $55 \mathrm{~km}$ altitude from MLS and the Water Vapor Millimeter-wave Spectrometer (WVMS) instruments (Nedoluha et al., 2011). The WVMS measurements are taken from Network for the Detection of Atmospheric Composition Change (NDACC) sites at Table Mountain (California, USA; Fig. 4a, b), Mauna Loa (Hawaii, USA; Fig. 4c, d), and Lauder (New Zealand; Fig. 4e, f). The MLS profiles have been smoothed using the WVMS averaging kernel. The WVMS retrievals use an MLS-based climatology, which includes seasonal variations but not interannual variations; thus, the WVMS measurements are not affected by the MLS drift. These comparisons, from the altitude region where the WVMS measurements are strongest, give no reason to reject a null hypothesis of zero drift between the two instruments. That said, in the case of Mauna Loa and Lauder, the $2 \sigma$ uncertainty encompasses the $\sim 2 \%$ per decade drift in the upper stratosphere estimated from MLS and ACE-FTS comparisons. The $2 \sigma$ uncertainty in the Table Mountain comparisons does not quite encompass such a drift. However, the large gap in the time series likely precludes robust interpretation of this comparison. Comparisons at other altitude regions (not shown) give similar results.

\subsubsection{Inferences from thermodynamic and microphysical studies}

Additional confirmation of a probable drift in the lowerstratospheric MLS v4 water vapor observations comes from a microphysical study building on the work of Lambert and Santee (2018), who examined MLS observations of polar winter lower-stratospheric nitric acid $\left(\mathrm{HNO}_{3}\right)$ and water vapor, along with coincident polar stratospheric cloud (PSC) observations from the Cloud-Aerosol Lidar with Orthogonal Polarization (CALIOP) instrument on the NASA/CNES Cloud-Aerosol Lidar and Infrared Pathfinder Satellite Observation (CALIPSO) mission. MLS and CALIOP data were used, in conjunction with a microphysical model of the equilibrium thermodynamics of supercooled ternary solutions (STSs) and ice clouds, to derive an independent measure of atmospheric temperature in the vicinity of PSCs. These estimated temperatures were then used to quantify the accuracy and precision of various reanalysis stratospheric temperature datasets. Figure 5a shows time series of average differences between this temperature estimate and temperature from the European Centre for Medium-Range Weather Forecasts (ECMWF) Interim (ERA-I) reanalysis, interpolated to the same locations, for 2008-2018. Colors indicate different pressure levels, as indicated in the legend. MLS and CALIOP measurements before 2008 and after 2018 were not sufficiently co-located to be included in this analysis. The implied drift in reanalysis temperature, assuming no drifts in the MLS and CALIOP data, is estimated to be $-0.35 \pm 0.04 \mathrm{~K}$ per decade. Only rarely does the Arctic winter polar vortex get cold enough to form large-scale water-ice PSCs, so this analysis is limited to the Antarctic.

Conversely, this analysis can be recast into one that provides insights into the MLS water vapor drift by instead assuming that the ERA-I temperatures are unbiased and, more critically, stable over the time frame considered. The latter assumption is quite reasonable given that, over this period, a consistent portfolio of observations were used in the ERA-I reanalysis (e.g., Long et al., 2017). The microphysical framework described above can then be used to derive an independent estimate of stratospheric water vapor in Antarctic 


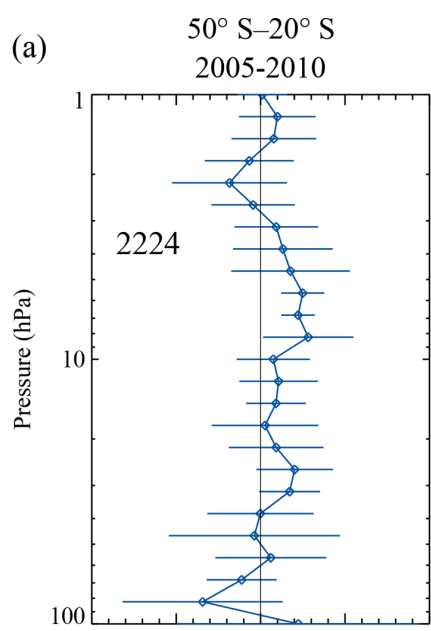

(d)

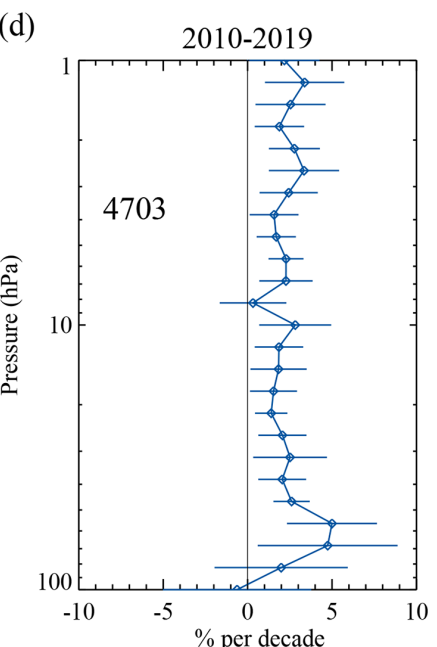

(b) $\quad 20^{\circ} \mathrm{S}-20^{\circ} \mathrm{N}$

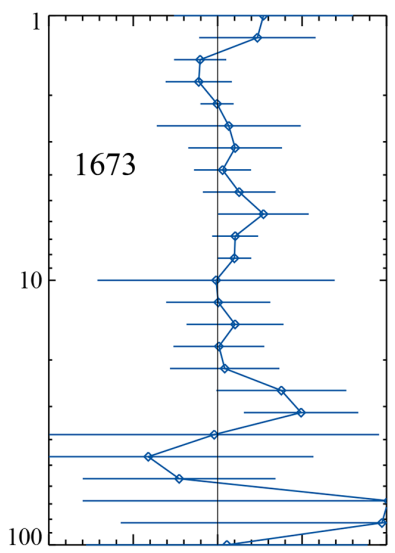

(e)

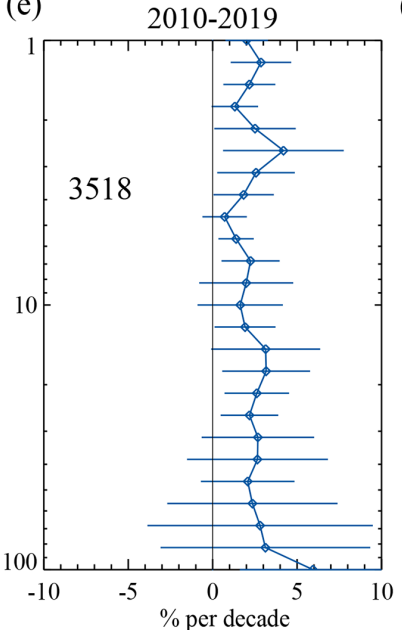

(c) $\quad 20^{\circ} \mathrm{N}-50^{\circ} \mathrm{N}$

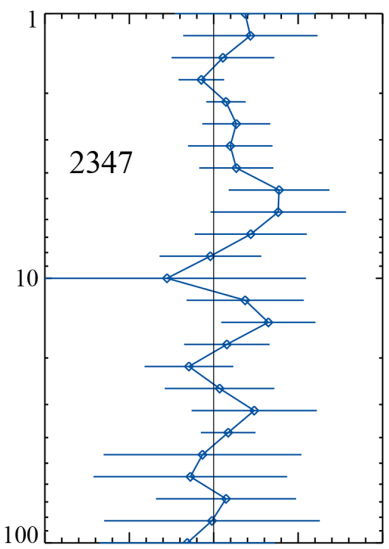

(f)

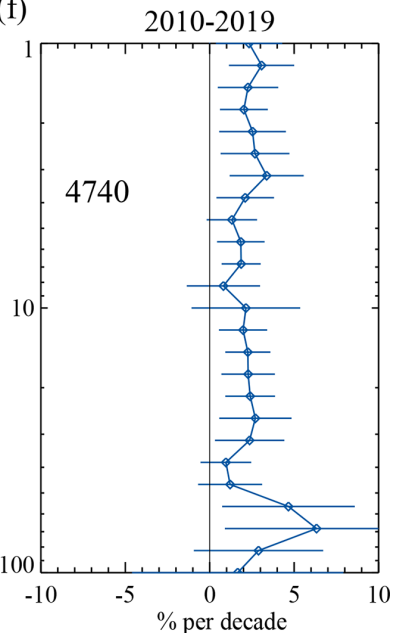

Figure 2. Drifts between MLS v4 and ACE-FTS version 4.1 observations of stratospheric water vapor for various latitude bands (columns) for 2005-2010 (a-c) and 2010-2019 (d-f). Numbers in each panel denote the total number of coincident (within $\pm 1^{\circ}$ latitude, $\pm 8^{\circ}$ longitude, and $\pm 12 \mathrm{~h}$ ) MLS/ACE observations, and error bars denote the $2 \sigma$ block bootstrap interval for the linear fit term. Positive numbers imply that MLS values are drifting upwards compared with those from ACE-FTS.

regions containing water-ice PSCs. Figure 5b shows the relationship between water vapor estimated using this approach and MLS v4 $\mathrm{H}_{2} \mathrm{O}$. This relationship exhibits a $6.7 \pm 0.8 \%$ per decade drift, with MLS v4 again moistening. In this case, the uncertainty corresponds to a simple $1 \sigma$ estimate from a linear least squares fit (i.e., with no bootstrapping).

\subsubsection{Water vapor summary}

We have found strong evidence for a drift in the MLS v4 water vapor dataset starting around 2010. Balloon measurements indicate statistically significant drifts as large as $11 \%$ per decade in the lower stratosphere. Comparisons with ACE-FTS show a smaller 2\%-3\% per decade drift over much of the vertical range, increasing to as much as $\sim 7 \%$ per decade in the lower stratosphere. Consideration of PSC microphysics in the Antarctic corroborates such a drift, and comparisons with ground-based microwave observations of lower-mesospheric water, while not showing any statistically significant drift, are largely not inconsistent with a $\sim 2 \%$ per decade drift. Comparisons with SABER lack sufficient statistical significance to comment on the drifts. We also note that Randel and Park (2019), who examined the time-lagged relationships between tropical tropopause cold-point temperature and lower-stratospheric humidity, found evidence for a positive drift in MLS v4 water vapor, peaking at 7\%-9\% per decade in the Northern Hemisphere lower stratosphere, consistent with the findings above.

\subsection{Ozone measured by the MLS $190 \mathrm{GHz}$ receiver}

Ozone has many strong lines throughout the microwave spectrum, with multiple lines in each of the spectral regions observed by MLS. The MLS ozone "standard product" is retrieved from radiances around $240 \mathrm{GHz}$, primarily selected because this region includes the strongest lines, providing in- 


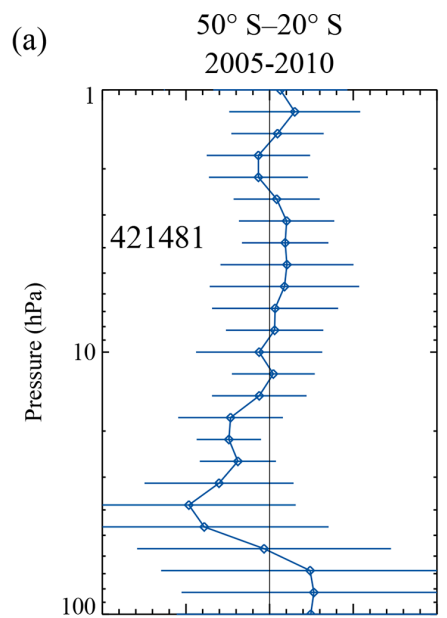

(b) $\quad 20^{\circ} \mathrm{S}-20^{\circ} \mathrm{N}$

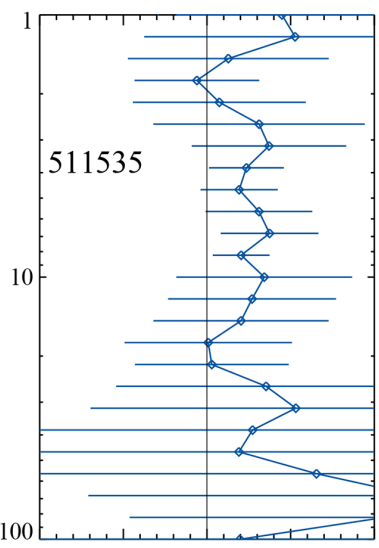

(d)

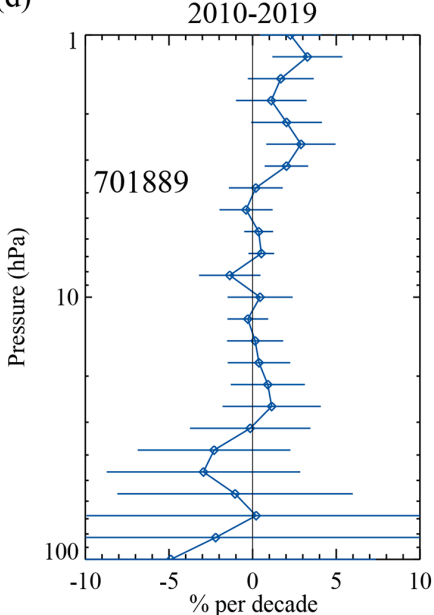

(e)

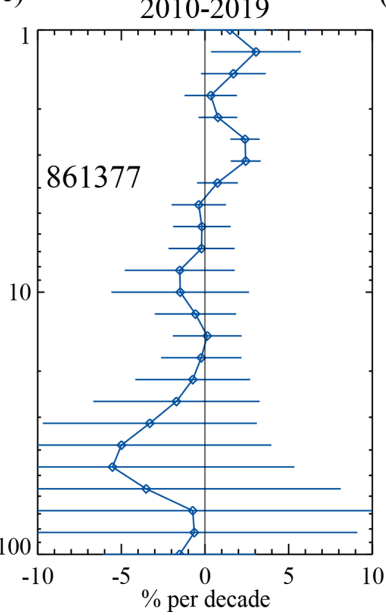

(c) $\quad 20^{\circ} \mathrm{N}-50^{\circ} \mathrm{N}$ 2005-2010

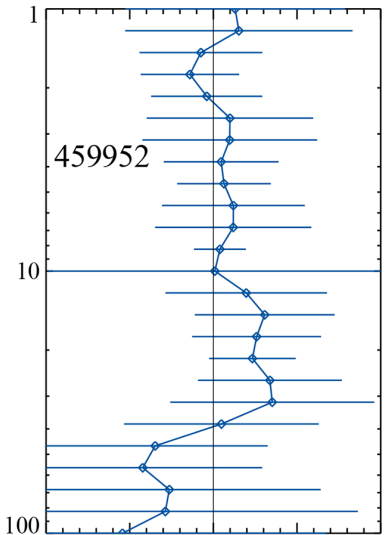

(f)

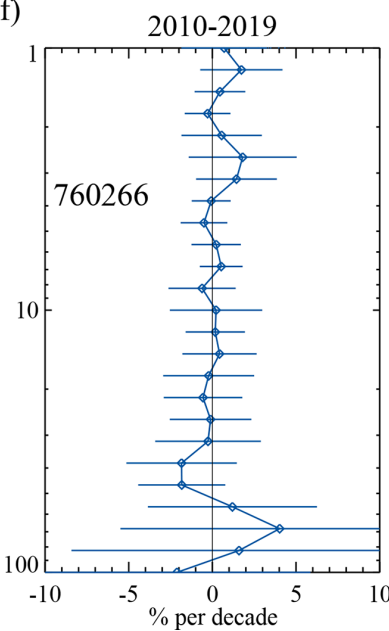

Figure 3. Figure 3 is the same as Fig. 2 but compares MLS v4 water vapor to SABER version 2.07.

formation over a broader altitude range than is available from the other receivers, spanning from the upper troposphere to the upper mesosphere. Ozone profiles are also retrieved from each of the other four MLS spectral regions, including from strong signals in the 190 and $640 \mathrm{GHz}$ receivers. Ozone signals at $118 \mathrm{GHz}$ and $2.5 \mathrm{THz}$ are noisier and, in the latter case, time limited, so they are not considered here. The MLS 190 and $640 \mathrm{GHz}$ ozone data products can be found in the "L2GP-DGG" data files.

Initial validation of MLS stratospheric ozone focused on the version 2 dataset (Jiang et al., 2007; Froidevaux et al., 2008), and average differences between that version and subsequent versions have been small, apart from some vertical oscillations (mainly at low latitudes), which have been reduced in the $\mathrm{v} 4$ data compared with previous versions (see Livesey et al., 2020). As noted above, the standard MLS stratospheric ozone product has been shown to be "very stable" in comparison to long-term coincident profiles from ozonesondes and lidars (Hubert et al., 2016); specifically, MLS stratospheric ozone exhibits small or negligible drifts (mostly under $1 \%-2 \%$ per decade) relative to those "ground truth" networks.

Figure 6a shows an example of monthly zonal mean ozone time series (2005 through 2019) from the MLS 190, 240, and $640 \mathrm{GHz}$ spectral bands in v4. These MLS observations are aggregated from monthly sets of typically hundreds of daily (day and night) co-located measurements in different latitude bins, and the resulting monthly zonal mean variations measured by the different MLS bands track each other very well. A strong quasi-biennial oscillation (QBO) signal is seen when anomaly time series are computed (Fig. 6b), with the ozone measurements from the different MLS bands again tracking each other well. Taking differences between the anomalies of the individual ozone products (Fig. 6c) removes essentially all of this interannual variability, leaving signals with small relative variability, from which simple linear fits indicate robust drifts in some of the inter-product differences. A drift in the $190 \mathrm{GHz}$ time series seen (in blue) in Fig. $6 \mathrm{a}$ and $\mathrm{b}$ is highlighted by the inter-product differences shown in Fig. 6c. 

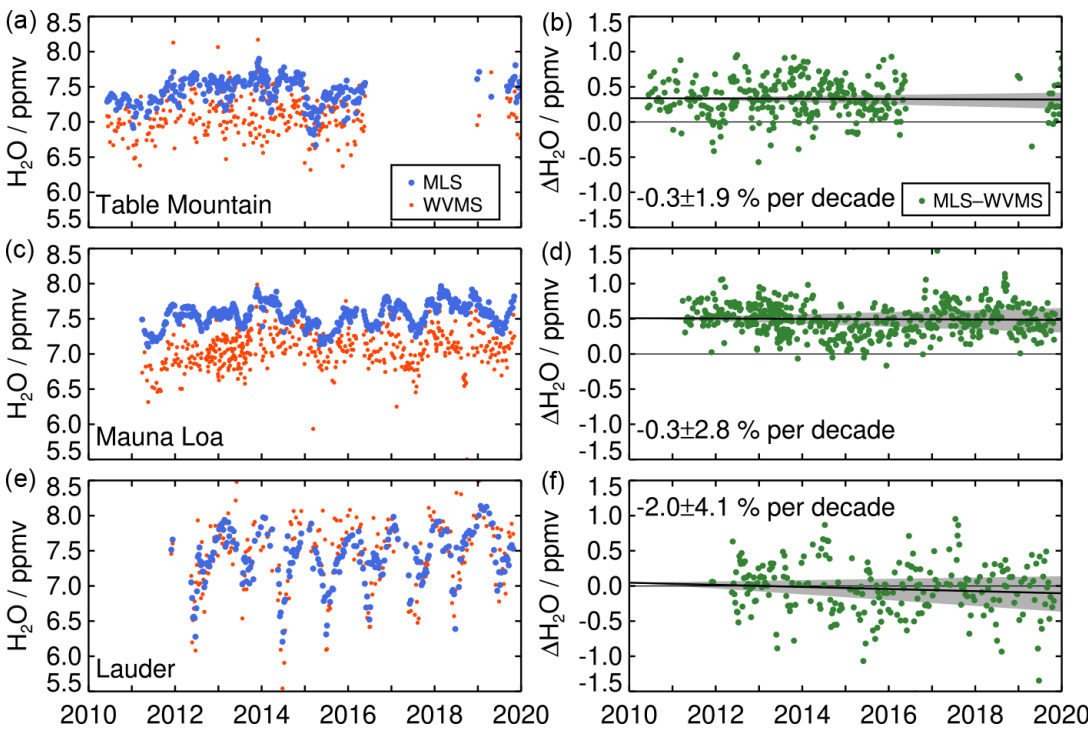

Figure 4. Panels (a), (c), and (e) show WVMS observations of $55 \mathrm{~km}$ lower-mesospheric water vapor in red and coincident (within $\pm 2^{\circ}$ latitude and $\pm 30^{\circ}$ longitude) MLS observations in blue. The WVMS data are from roughly week-long integrations, and the MLS points are averages of all spatially coincident observations in a 1-week window centered on the middle of each WVMS observation period. Panels (b), (d), and (f) show the corresponding differences (MLS minus WVMS) and an associated linear fit (with shading indicating the 1-year block bootstrap $95 \%$ confidence range for the slope). Drift rates (converted from ppmv to percent) and an associated $2 \sigma$ uncertainty are quoted in each panel.
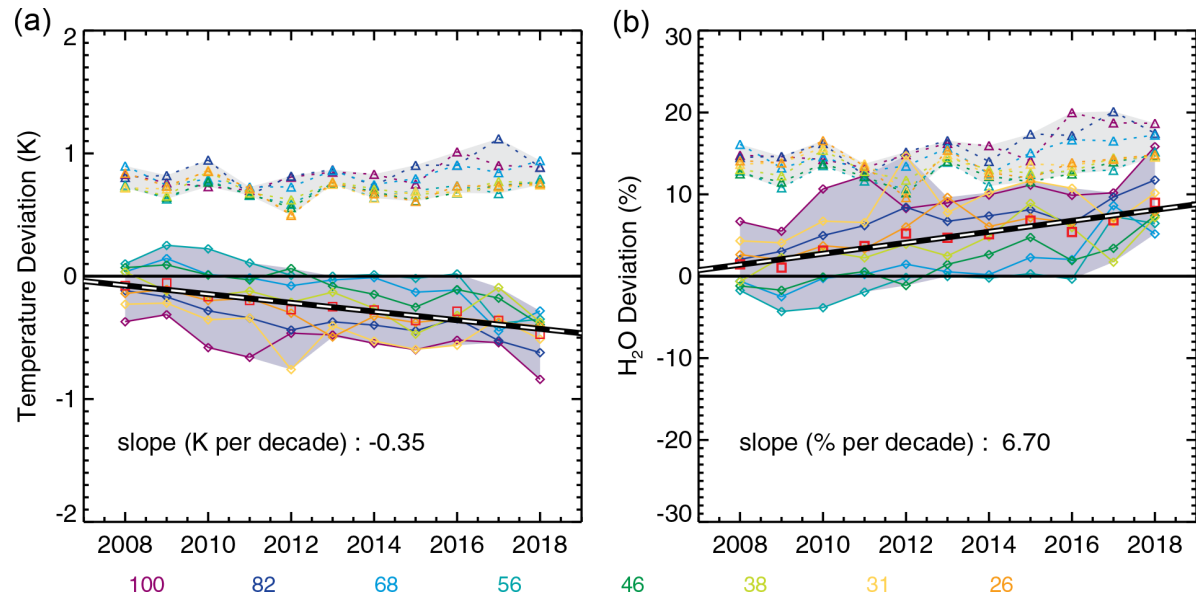

Figure 5. (a) $\mathrm{MLS} \mathrm{H}_{2} \mathrm{O}$ is used to calculate the water-ice frost point (in the presence of CALIOP ice PSCs) for observations south of $60^{\circ} \mathrm{S}$, between 100 and $26 \mathrm{hPa}$ and days 140 and 230 of each year. The annually and spatially averaged difference between the interpolated ERA-I temperature and the MLS-calculated frost point is shown by the solid lines with diamonds. Colors indicate the MLS pressure levels (hPa; see legend). Shading encompasses the range of deviations for all pressure levels considered, and the red squares are the means over all pressure levels. Triangles connected with dotted lines show the standard deviations of the individual differences (with shading again indicating the range of these values). Panel (b) shows the equivalent differences and standard deviations if the ERA-I temperatures are taken to be unbiased and stable and the same microphysical calculations are instead used to provide an estimate of water vapor. This is then compared to MLS water vapor observations (MLS minus estimates from microphysics).

Profiles of the resulting drifts between MLS ozone time series from the different bands are displayed in Fig. 7, for different time periods for $50^{\circ} \mathrm{S}-50^{\circ} \mathrm{N}$. Drifts at higher latitudes (poleward of $50^{\circ}$ ) or in narrower latitude ranges (not shown) are generally consistent with those in Fig. 7. These compar- isons conclusively indicate that, in the MLS v4 record, the $190 \mathrm{GHz}$ ozone measurements are drifting compared with both the $240 \mathrm{GHz}$ and the $640 \mathrm{GHz}$ ozone measurements, whereas the latter two show essentially no drift in their differences. As with earlier results, error bars shown are $2 \sigma$ 

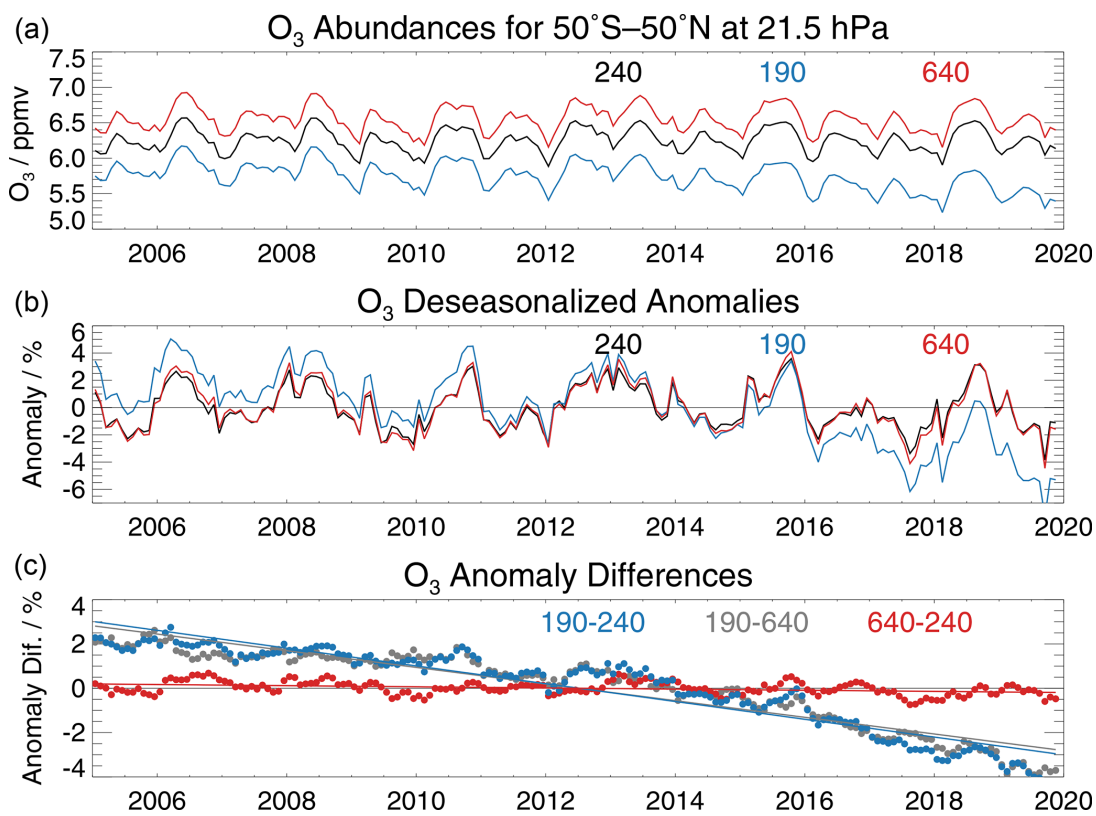

Figure 6. Panel (a) shows a time series of MLS monthly mean ozone measurements from the 190, 240, and $640 \mathrm{GHz}$ receivers at $21.5 \mathrm{hPa}$ between $50^{\circ} \mathrm{S}$ and $50^{\circ} \mathrm{N}$. Panel (b) shows the same time series as deseasonalized anomalies (in \%). Panel (c) shows time series of differences between those anomalies for the various combinations of receiver pairs, along with simple linear fits.

bounds, from a block bootstrap resampling (with replacement, using year-long blocks). Both Figs. 6 and 7 also show larger drifts in $190 \mathrm{GHz}$ ozone in more recent years. Results from the first period (2005-2009; Fig. 7a) show very little drift (within the error bars), while the full time period (Fig. 7b) and especially the 2010-2019 period (Fig. 7c) show worsening drifts for the $190 \mathrm{GHz}$ ozone product versus the other two MLS v4 ozone products. At $22 \mathrm{hPa}$ and smaller pressures (higher altitudes), the $190 \mathrm{GHz}$ ozone product exhibits statistically significant drifts with respect to the 240 and $640 \mathrm{GHz}$ results, with values of about $-3 \%$ per decade for the overall period (2005-2019); most of the drift occurs after 2010 , at a rate of about $-4 \%$ per decade. Drifts over the 100-22 $\mathrm{hPa}$ pressure range are less consistent in sign, although still statistically significant in some cases. However, the low abundances of ozone at these levels make reliable assessment of fractional drifts challenging.

\section{$2.3 \quad \mathrm{~N}_{2} \mathrm{O}$ from MLS 190 and $640 \mathrm{GHz}$ measurements}

In MLS Level 2 versions 3 and earlier, the standard product for $\mathrm{N}_{2} \mathrm{O}$ was obtained from the $640 \mathrm{GHz}$ receiver. However, this measurement had to be discontinued in June 2013 because of rapid degradation in the $\mathrm{N}_{2} \mathrm{O}$-specific elements of the $640 \mathrm{GHz}$ signal chain resulting from a component failure. In order to provide a consistent $\mathrm{N}_{2} \mathrm{O}$ record for the entire MLS observation period, the $\mathrm{N}_{2} \mathrm{O}$ standard product for $\mathrm{v} 4$ (and later versions) is instead obtained from $190 \mathrm{GHz}$ radiances. Characteristics of the two MLS $\mathrm{N}_{2} \mathrm{O}$ products and their differences are discussed in the MLS data qual- ity document (Livesey et al., 2020). Although agreement is good overall, the v4 $190 \mathrm{GHz} \mathrm{N} \mathrm{N}_{2} \mathrm{O}$ product has a moderate high bias at $68 \mathrm{hPa}$ and a strong high bias at $100 \mathrm{hPa}$. Consequently, the $100 \mathrm{hPa} 190 \mathrm{GHz} \mathrm{N} \mathrm{N}_{2} \mathrm{O}$ data are not recommended for scientific use in $\mathrm{v} 4$.

The v4 $190 \mathrm{GHz} \mathrm{N} \mathrm{N}_{2} \mathrm{O}$ retrievals have drifted with respect to the $640 \mathrm{GHz} \mathrm{N} \mathrm{N}_{2} \mathrm{O}$ data, as shown in an analysis of the 8 years of available $640 \mathrm{GHz}$ data from 2005 through 2012 (Fig. 8). These results are obtained in the same manner as those for ozone discussed above but for just the two $\mathrm{N}_{2} \mathrm{O}$ bands through 2012. Although the values depend slightly on latitude, in general there are relative drifts from -3 to $-5 \%$ per decade near 46 to $68 \mathrm{hPa}$, diminishing to near-zero drift at 10 to $15 \mathrm{hPa}$ (with no clear drift seen in the upper stratosphere, not shown). For comparison, the ozone drifts for the same radiometers $(190$ versus $640 \mathrm{GHz})$ are shown for the same period (dashed lines). Between 46 and $10 \mathrm{hPa}$, the $190 \mathrm{GHz}$ ozone and $\mathrm{N}_{2} \mathrm{O}$ drifts agree within their respective error bars.

Surface observations show that tropospheric abundances of $\mathrm{N}_{2} \mathrm{O}$ are increasing by $2.6 \%$ per decade (World Meteorological Organization, 2014), and models predict that this results in an increasing trend in stratospheric $\mathrm{N}_{2} \mathrm{O}$ abundance. As shown by Froidevaux et al. (2019), MLS v4 tropical lower-stratospheric $640 \mathrm{GHz} \mathrm{N} \mathrm{N}_{2} \mathrm{O}$ displays a positive trend of the order of $1 \%$ per decade for 2005-2012, with error bars encompassing the range from zero up to more than $2 \%$ per decade (Fig. 9), consistent with (although on the low side of) tropospheric $\mathrm{N}_{2} \mathrm{O}$ trends. In contrast, the tropical lowerstratospheric MLS v4 $190 \mathrm{GHz} \mathrm{N} \mathrm{N}_{2} \mathrm{O}$ trends have values of 

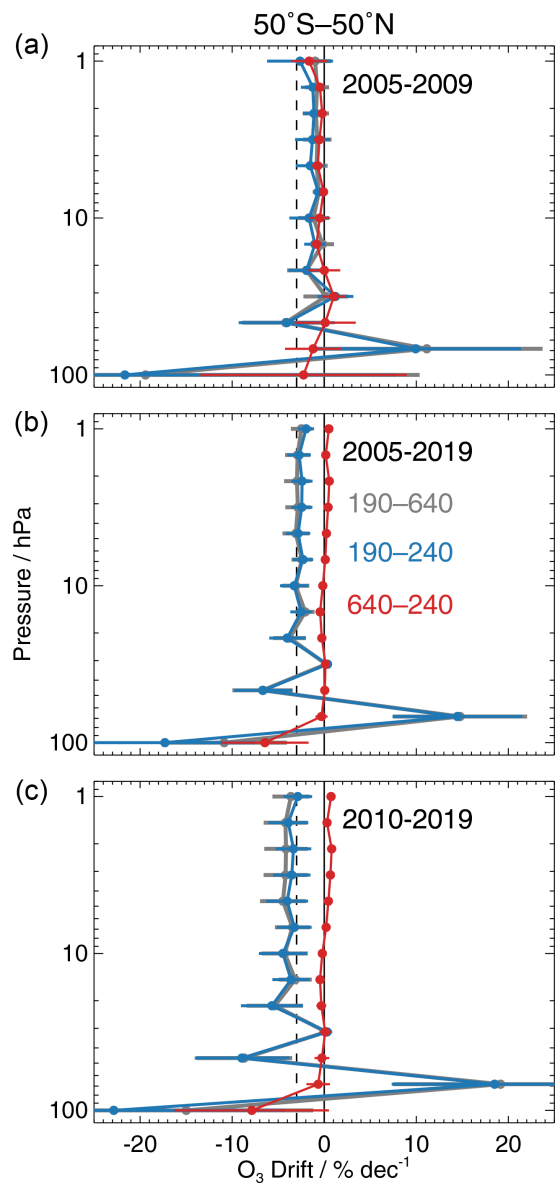

Figure 7. Profiles of linear fits obtained from differences between the MLS v4 ozone products based on the 190,240 , and $640 \mathrm{GHz}$ receivers over $50^{\circ} \mathrm{S}-50^{\circ} \mathrm{N}$ for different time periods (see legend). Error bars are $2 \sigma$ intervals estimated from block bootstrapping. The solid vertical line marks zero drift, and the dashed vertical line indicates a $-3 \%$ per decade drift.

-1 to $-2 \%$ per decade. Stronger negative tendencies in v4 $190 \mathrm{GHz} \mathrm{N} 2 \mathrm{O}$ are seen in the years since 2014 (not shown, see Froidevaux et al., 2019).

Figure 10 presents further confirmation of a drift in the

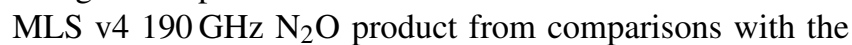
ACE-FTS record, employing the same $\pm 1^{\circ}$ latitude, $\pm 8^{\circ}$ longitude, and $\pm 12 \mathrm{~h}$ coincidence criteria as Fig. 2 . These comparisons show the $190 \mathrm{GHz} \mathrm{N} \mathrm{N}_{2} \mathrm{O}$ drift having a more pronounced vertical gradient than is seen in $\mathrm{H}_{2} \mathrm{O}$ and $\mathrm{O}_{3}$, with no significant drift in the mid-stratosphere and a very strong, and statistically significant, drift of around $-15 \%$ per decade ( $\pm \sim 10 \%$ per decade) during 2010-2019 in the lower stratosphere. For comparison, preliminary studies (not shown) quantifying 2004-2020 drifts between the ACE-FTS $\mathrm{N}_{2} \mathrm{O}$ record and the newly released "version v3.0" $\mathrm{N}_{2} \mathrm{O}$ dataset from the Odin Submillimeter Radiometer (SMR; Murtagh et al., 2002) indicate a $\sim 3 \%-4 \%$ per decade drift in the lower stratosphere, with ACE-FTS increasing.
In summary, the MLS $\mathrm{v} 4190 \mathrm{GHz} \mathrm{N_{2 }} \mathrm{O}$ product shows a significant negative drift, with $-3 \%$ per decade seen in comparisons with the MLS $640 \mathrm{GHz}$ observations from 2005 to 2012. These comparisons also indicate a faster drift at higher latitudes (not shown), as mentioned in Strahan and Douglass (2018). Drifts as large as $-15 \%$ per decade over 2010-2019 are seen in the lower stratosphere compared with ACE-FTS, with even larger drifts seen at $100 \mathrm{hPa}$, a level that is not recommended for scientific use in the MLS v4 dataset. These results are consistent with those of Errera et al. (2019), who found a drift of 5\%-7\% between MLS and measurements by both ACE-FTS and the Michelson Interferometer for Passive Atmospheric Sounding (MIPAS) on Envisat (Fischer et al., 2008) during 2005-2012, with $10 \%$ drifts seen compared with ACE-FTS for the 2005-2017 period.

\section{Insights into causes of the drifts, and pathways to their partial amelioration}

\subsection{A drift in the $190 \mathrm{GHz}$ "sideband fraction"}

The MLS instrument observes thermal microwave emission from the Earth's limb. The radiance signals from which all of the MLS products discussed in this paper are derived are received by a $1.6 \mathrm{~m}$ primary "GHz" antenna. This antenna scans the limb vertically from the surface to $\sim 90 \mathrm{~km}$ altitude every $\sim 24.6 \mathrm{~s}$, looking in the forward direction from the Aura spacecraft (a separate "THz" antenna is used for measuring the $\mathrm{OH}$ radical). The microwave signals are then passed through a series of splitters that subdivide the signals into four spectral regions: $118 \mathrm{GHz}$ (for which there are two independent receivers), 190, 240, and $640 \mathrm{GHz}$. All of the MLS receivers employ the heterodyne detection approach, whereby atmospheric signals are mixed with a signal from a local oscillator (LO) in a nonlinear signal element such as a diode. This nonlinear mixing results in intermediatefrequency (IF) signals that effectively correspond to the atmospheric spectrum in the region near the LO frequency, $f_{\mathrm{LO}}$, but shifted down in frequency by an amount equal to $f_{\mathrm{LO}}$. The parts of the original spectra below $f_{\mathrm{LO}}$ are shifted to negative IF space, essentially "folding" them on top of the positive IF signals that correspond to the original spectra above $f_{\mathrm{LO}}$. Thus, the IF signal is a superposition of the original signals above and below $f_{\mathrm{LO}}$. Mathematically speaking,

$$
\begin{aligned}
& S_{\mathrm{IF}}\left(f_{\mathrm{IF}}\right)=\alpha\left(f_{\mathrm{IF}}\right) S_{\mathrm{atm}}\left(f_{\mathrm{LO}}-f_{\mathrm{IF}}\right) \\
& +\beta\left(f_{\mathrm{IF}}\right) S_{\mathrm{atm}}\left(f_{\mathrm{LO}}+f_{\mathrm{IF}}\right),
\end{aligned}
$$

where $S_{\text {atm }}(f)$ is the atmospheric spectrum (e.g., between 176 and $208 \mathrm{GHz}$ for the MLS " $190 \mathrm{GHz}$ " signals, for which $\left.f_{\mathrm{LO}}=191.9 \mathrm{GHz}\right)$, and $S_{\mathrm{IF}}\left(f_{\mathrm{IF}}\right)$ is the resulting IF spectrum (between 0 and $\sim 16 \mathrm{GHz}$ for the $190 \mathrm{GHz}$ example). The terms $\alpha$ and $\beta$ are IF-dependent sideband fractions describing the contribution to the IF signal from atmospheric signals below and above the LO frequency, respectively. In 


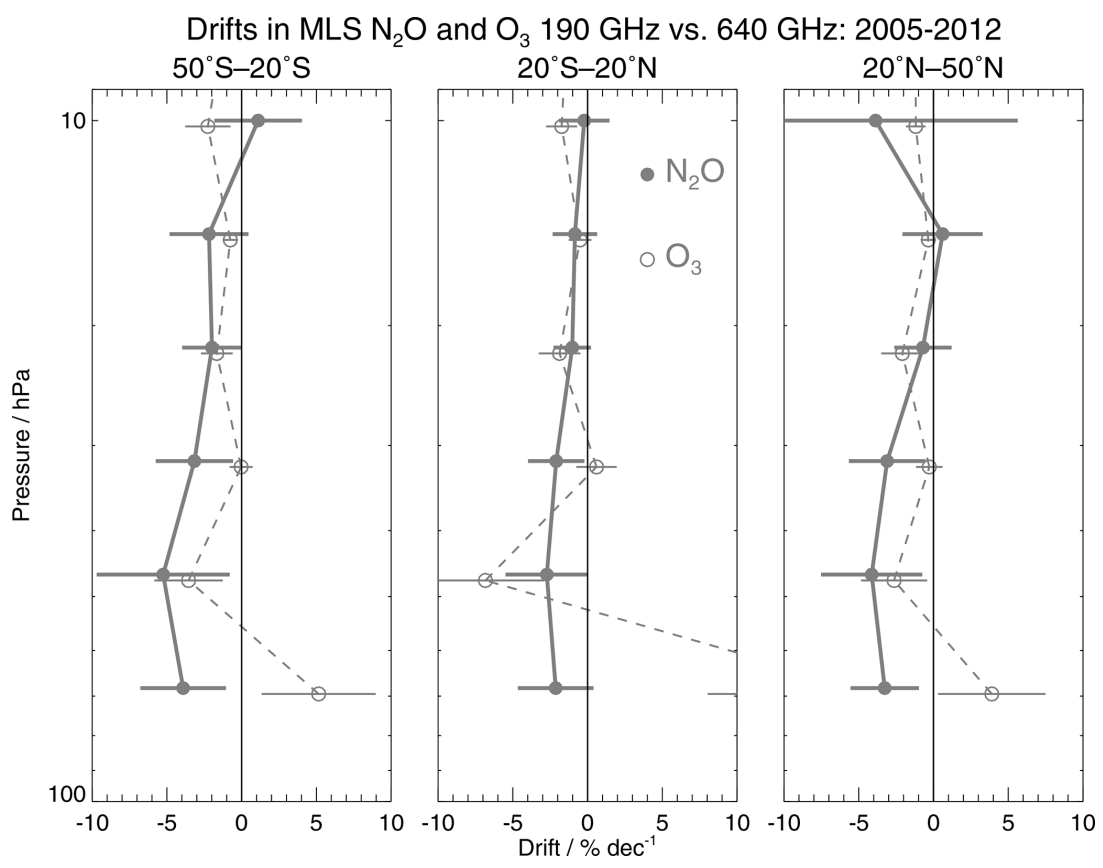

Figure 8. Drifts between MLS 190 and $640 \mathrm{GHz} \mathrm{N} 2 \mathrm{O}$ products from 2005 to 2012 over three latitude bins. Also shown (dashed line) is the corresponding drift seen between MLS 190 and $640 \mathrm{GHz}$ ozone. Error bars are $2 \sigma$ intervals estimated from block bootstrapping, as described in the text.

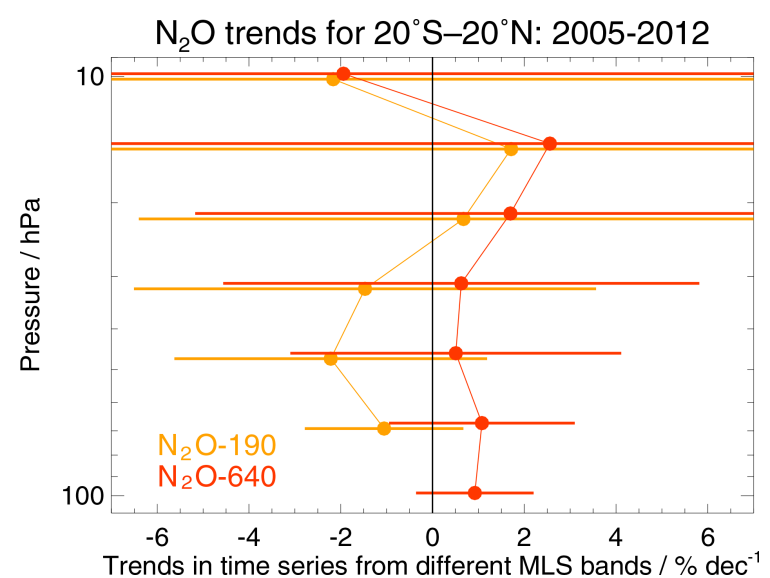

Figure 9. The 2005-2012 trend seen in MLS 190 and $640 \mathrm{GHz}$ tropical $\left(20^{\circ} \mathrm{S}-20^{\circ} \mathrm{N}\right) \mathrm{N}_{2} \mathrm{O}$. Error bars are $2 \sigma$ intervals estimated from block bootstrapping.

most cases, these sideband fractions are around 0.5, while for the $118 \mathrm{GHz}$ receiver, the upper-sideband signals are blocked by a waveguide filter, giving $\alpha \simeq 1$ and $\beta \simeq 0$. In practice, factors related to the MLS calibration scheme and non-negligible thermal emission from the primary antenna and other optics dictate that the sum of $\alpha$ and $\beta$ typically falls slightly short of unity, but that has no consequence for the issues discussed here.

Figure 11 shows illustrative simulated atmospheric spectra and intermediate-frequency spectra for the $190 \mathrm{GHz}$ signals
Table 1. The key spectral lines in the MLS $190 \mathrm{GHz}$ band $\left(f_{\mathrm{LO}}=\right.$ $191.9 \mathrm{GHz})$.

\begin{tabular}{llll}
\hline Molecule & Frequency $(\mathrm{GHz})$ & Sideband & Drift direction \\
\hline $\mathrm{H}_{2} \mathrm{O}$ & $183.3 \mathrm{GHz}$ & Lower & Increasing \\
$\mathrm{O}_{3}$ & $206.1 \mathrm{GHz}$ & Upper & Decreasing \\
$\mathrm{N}_{2} \mathrm{O}$ & $201.0 \mathrm{GHz}$ & Upper & Decreasing \\
\hline
\end{tabular}

that are central to the MLS products affected by the drift described above. The spectral lines that give rise to the MLS $190 \mathrm{GHz}$ products are listed in Table 1, which also summarizes the drift direction for each product. As summarized in the table, water vapor (in the lower sideband) shows an increasing drift, whereas ozone and $\mathrm{N}_{2} \mathrm{O}$ (upper sideband) exhibit a decreasing drift compared with MLS observations in other spectral regions and with other data records. This strongly implies that a slow change in sideband fractions, with the lower sideband being increasingly favored, is at least partly responsible for the observed behavior.

\subsection{Other MLS $190 \mathrm{GHz}$ data products}

The standard product for $\mathrm{HNO}_{3}$ uses radiances from lines in the $190 \mathrm{GHz}$ region for pressures smaller than $22 \mathrm{hPa}$ (with $240 \mathrm{GHz}$ information used at larger pressures). Much of the $190 \mathrm{GHz} \mathrm{HNO}_{3}$ information derives from a cluster of lines in the lower sideband. Accordingly, as with $\mathrm{H}_{2} \mathrm{O}$, an increasing drift should be expected in the MLS mid-stratosphere and 

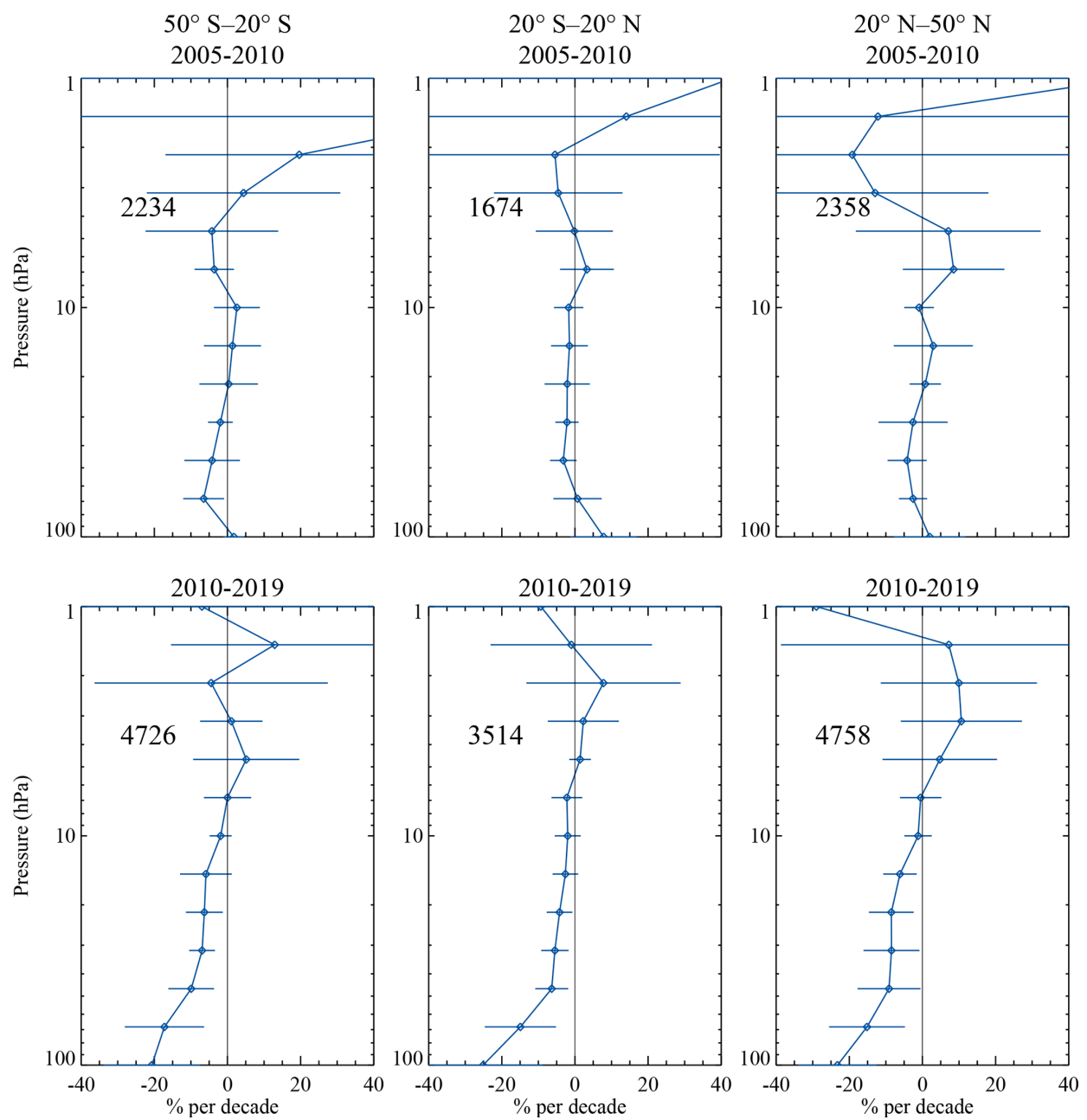

Figure 10. Figure 10 is the same as Fig. 2 but compares the MLS $190 \mathrm{GHz} \mathrm{N} \mathrm{O}_{2} \mathrm{O}$ product with the $\mathrm{N}_{2} \mathrm{O}$ measurements from ACE-FTS.

upper-stratospheric $\mathrm{HNO}_{3}$ product. However, comparisons with ACE-FTS (not shown) indicate no statistically significant drifts in the mid-stratosphere and upper stratosphere. This likely reflects the poor signal to noise for $\mathrm{MLS}_{\mathrm{HNO}}$ measurements at these altitudes, given the low abundance of $\mathrm{HNO}_{3}$. Additionally, $\mathrm{HNO}_{3}$ has a plethora of lines in the microwave spectrum, including many in the $190 \mathrm{GHz}$ upper sideband. This likely further dilutes the impact of drifts in the sideband fraction. Further to this point, we note that no consistent drift signals are seen in comparisons between the MLS measurements of $\mathrm{HNO}_{3}$ at 190,240 , and $640 \mathrm{GHz}$ (not shown).

The MLS HCN product derives from a cluster of lines around $177.3 \mathrm{GHz}$, in the $190 \mathrm{GHz}$ lower sideband. While an increasing drift is, therefore, expected in this product, comparisons with ACE-FTS (not shown) instead indicate a statistically significant decreasing drift in the lower stratosphere, ranging from $10 \%$ to $15 \%$ per decade at $100 \mathrm{hPa}$, decreasing to $5 \%$ per decade at $46 \mathrm{hPa}$. However, the MLS HCN product is known to be subject to systematic errors at these levels, with $22 \mathrm{hPa}$ being the largest pressure (lowest vertical level) at which this product is recommended for scientific use (Livesey et al., 2020). These errors likely originate from the significant overlap at these altitudes between the lowersideband HCN signals and a strong ozone line at $206.1 \mathrm{GHz}$, in the $190 \mathrm{GHz}$ upper sideband. (That ozone line, targeted by MLS band 6, provides the bulk of the information for the $190 \mathrm{GHz}$ ozone data product.) This overlap, combined with the drift in the retrieved $190 \mathrm{GHz}$ ozone product, likely accounts for the unexpected sign of the HCN drift.

\subsection{Quantifying sideband fraction}

Although the MLS sideband fractions were measured as part of the prelaunch MLS calibration (Jarnot et al., 2006), investigation has shown that (in contrast with those of the other MLS receivers) the $190 \mathrm{GHz}$ post-launch sideband fractions are not only different from the prelaunch-measured values but are also slowly drifting. This has been found through careful analysis of the in-orbit MLS radiance observations 

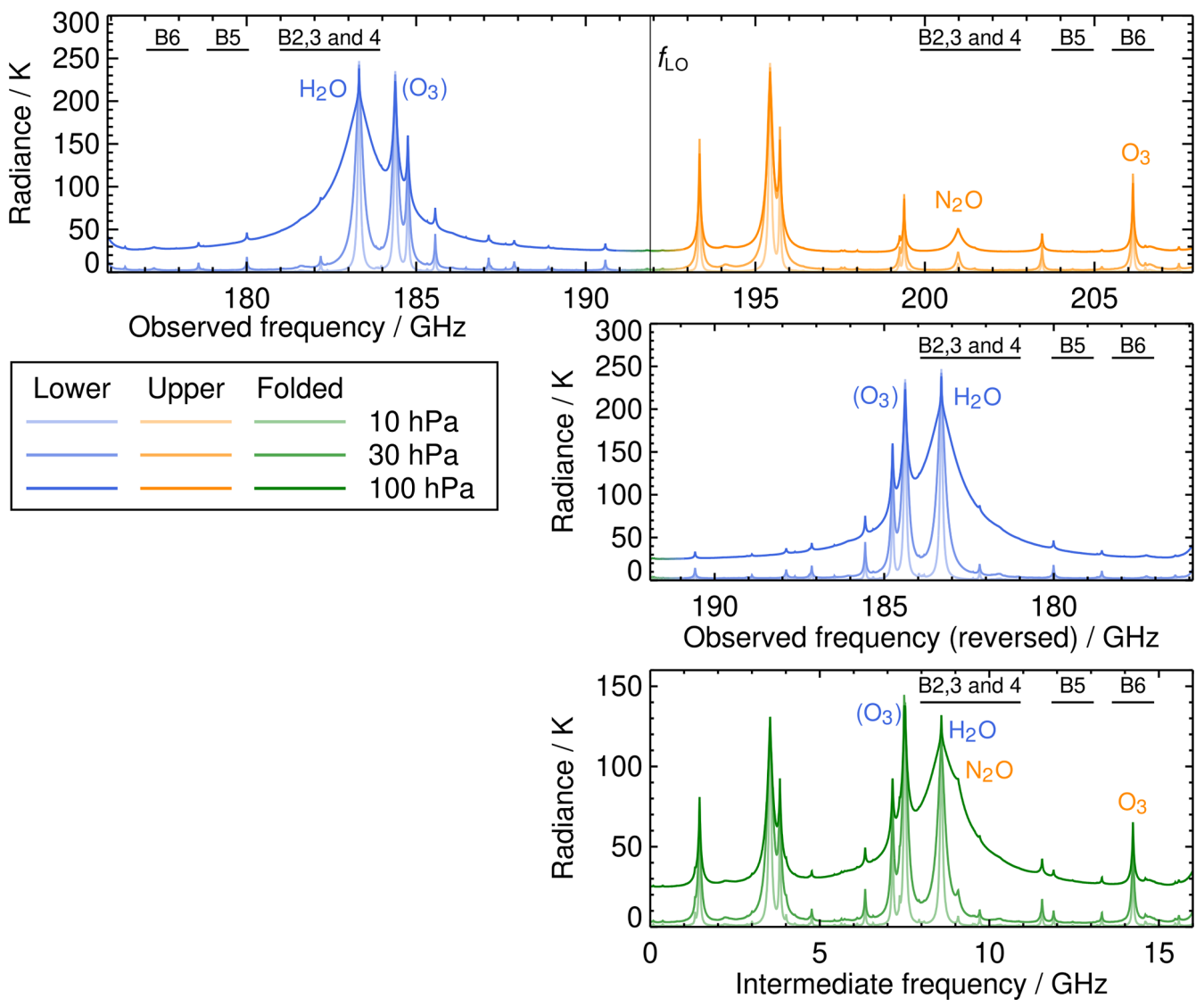

Figure 11. Illustration of the $190 \mathrm{GHz}$ spectral region observed by Aura MLS and of the "sideband folding" heterodyne down-conversion process. The top row shows the atmospheric spectrum observed by MLS on either side of the local oscillator at $f_{\mathrm{LO}}=191.9 \mathrm{GHz}$ for tangent points at 10,30 , and $100 \mathrm{hPa}$ (pale to dark colors). The second row shows the "lower-sideband" $\left(f<f_{\mathrm{LO}}\right)$ signal folded about $f_{\mathrm{LO}}$ (note the reversed $x$ axis). The bottom plot shows the intermediate-frequency $(0-16 \mathrm{GHz})$ signal corresponding to a 50/50 sum of the lower- and upper-sideband signals. The locations of MLS spectral bands 2-6 are specified (bands 2, 3, and 4 overlap significantly and are shown with a single line). The key spectral lines for water vapor, ozone, and $\mathrm{N}_{2} \mathrm{O}$ are identified, with color denoting the sideband in which the line is found. Note that the two ozone lines around $184 \mathrm{GHz}$ (labeled parenthetically) are not covered by any MLS spectral bands. The bulk of the ozone information from the MLS $190 \mathrm{GHz}$ spectral region instead derives from the $206 \mathrm{GHz}$ line in the upper sideband covered by band 6 . MLS bands 4 and 5 measure $\mathrm{HNO}_{3}$ and $\mathrm{ClO}$, respectively, whose signals are too small to be seen clearly on this plot.

in specific channels over limited altitude ranges, where the observed signal is a combination of a large optically thick radiance in one sideband and a small optically thin radiance in the other. More precisely, when viewed at limb tangent altitudes around $30 \mathrm{hPa}$, the region in the center of the $183 \mathrm{GHz}$ $\mathrm{H}_{2} \mathrm{O}$ line (located in the lower sideband) is optically thick (due to the strong absorption by water vapor); signals from this line are combined with those in the optically thin spectral region in the upper sideband. As it is optically thick, the signal in the saturated line-center region of the lower sideband is only weakly affected by the abundance of water vapor (or any other species) and is essentially a measure of temperature in the region of the upper stratosphere where limb rays first become optically thick at these frequencies. This signal is multiplied by the lower-sideband fraction, which effectively acts as a scaling factor for the atmospheric signal. The upper-sideband signal, by contrast, is very small at these altitudes and is largely determined by dry-air and water vapor continua. Given knowledge of the atmospheric temperature profile (e.g., from MLS radiance observations in other spectral regions, and/or from meteorological analysis fields), the expected radiance signal in both sidebands can be readily estimated using a "forward model" radiance calculation and compared to the observed radiances. Such forward model calculations are routinely performed as part of the MLS Level 2 processing.

Figure 12 shows a time series of such radiance differences (observed minus calculated, i.e., the difference between the measured radiances and those predicted from forward model calculations and prelaunch measurements of $\alpha$ and $\beta$ according to Eq. 1) and a comparable calculation for the channels in the center of the $235 \mathrm{GHz} \mathrm{O}_{3}$ line measured with the MLS $240 \mathrm{GHz}$ receiver. The $183 \mathrm{GHz}$ radiance differences have a baseline of $\sim 8 \mathrm{~K}$ after launch, show a significant $\sim 0.7 \mathrm{~K}$ 

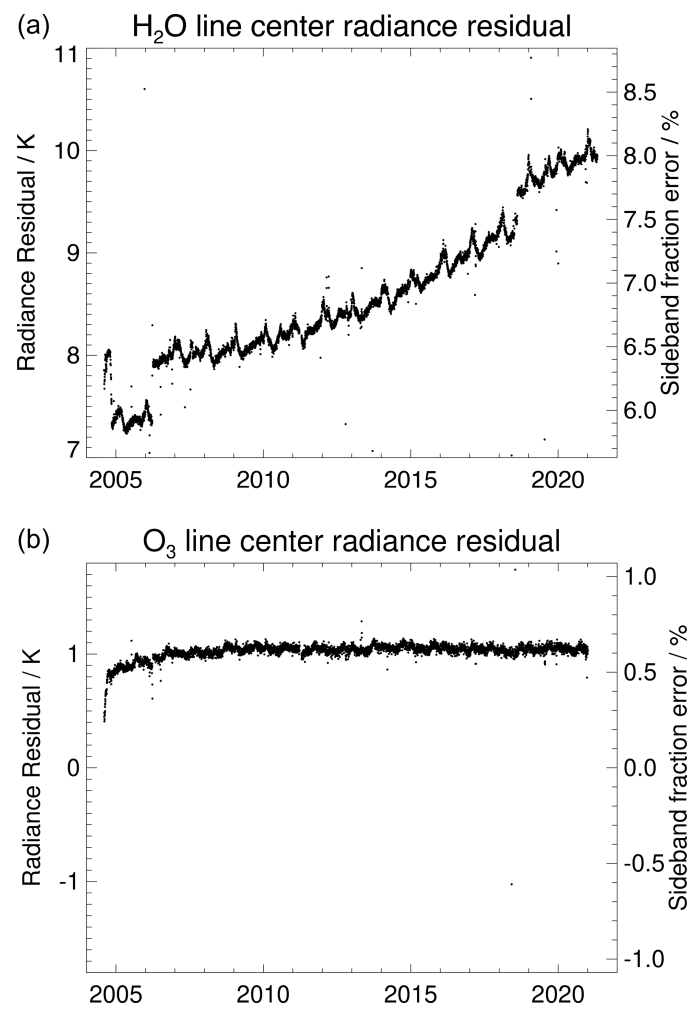

Figure 12. Difference between radiances observed in the center of the water vapor $(\mathbf{a}, 183 \mathrm{GHz})$ and ozone $(\mathbf{b}, 235 \mathrm{GHz})$ lines and those predicted using the MLS forward model and retrieved temperature for limb tangents around $31 \mathrm{hPa}$. The offset and temporal variability in the water vapor case is a measure of changes in the $190 \mathrm{GHz}$ sideband fraction from the prelaunch estimate (approximately shown on the right $y$ axis).

drop in late 2004, and then display a comparable increase in early 2006. Those changes are followed by a slow increasing trend from $\sim 8 \mathrm{~K}$ in early 2006 to $\sim 10 \mathrm{~K}$ in late 2019 (with a strong increase in the late-2018 time frame). In contrast, $235 \mathrm{GHz}$ radiance differences are stable to within $\sim 0.1 \mathrm{~K}$ or better, and the absolute offset is only $\sim 1 \mathrm{~K}$, which is reasonable given the expected accuracy of the MLS-derived temperature fields used (which also include information from the NASA Global Modeling and Assimilation Office's "Forward Processing for Instrument Teams" data stream) and other assumptions in this calculation.

Other than a change in sideband fractions, the most plausible alternative factor that could give rise to the post-2010 drifting behavior of the $183 \mathrm{GHz}$ signals shown in Fig. 12 would be some time-dependent variation in the MLS temperature dataset (which would need to change by an amount comparable to the $\sim 2 \mathrm{~K}$ change in radiance residual). We see no signs of such a drift in comparisons of the MLS temperature product with other datasets. Furthermore, such a temperature drift would affect both the 190 and the $240 \mathrm{GHz}$ calculations in Fig. 12 in a similar manner. The right $y$ axis in each panel of Fig. 12 shows the approximate sideband fraction change (compared with the prelaunch calibration value) that would account for the difference between observed and calculated radiances, obtained by solving Eq. (1) for $\alpha\left(f_{\mathrm{IF}}\right)$ and $\beta\left(f_{\mathrm{IF}}\right)$ using MLS observations of $S_{\mathrm{IF}}\left(f_{\mathrm{IF}}\right)$ and forward model estimates of $S_{\mathrm{atm}}\left(f_{\mathrm{LO}}-f_{\mathrm{IF}}\right)$ and $S_{\mathrm{atm}}\left(f_{\mathrm{LO}}+f_{\mathrm{IF}}\right)$, in conjunction with an estimate of $\alpha\left(f_{\mathrm{IF}}\right)+\beta\left(f_{\mathrm{IF}}\right)$, a sum that is close to unity, obtained from instrument calibration.

The drop in the $190 \mathrm{GHz}$ sideband fraction seen in late 2004 , with a "recovery" in early 2006 , is associated with a period when the MLS optical bench was maintained at a different temperature compared with that selected for the rest of the mission. Similarly, the discontinuity in late 2018 corresponds to a change in an attenuator setting in the MLS band 2 signal chain. The fact that this receiver's sideband fraction appears to be affected by such changes in operating conditions implies that it is not as stable as was intended; thus, it is likely also affected by other parameters. In other words, the observed drift in sideband fractions is likely to be a symptom of aging in some more fundamental receiver parameter that is not directly measured within the MLS instrument. Further, we should not assume that the sideband fraction drift is the only consequence of such aging - other calibration parameters may be drifting also, in less obviously identifiable ways, contributing to the drifts seen in the MLS $190 \mathrm{GHz}$ observations.

The $\sim 8 \mathrm{~K}$ post-launch offset in the $183 \mathrm{GHz}$ radiance differences in the saturated line-center region, corresponding to $\mathrm{a} \sim 6.5 \%$ change in sideband fraction, is also notable. Again, this is likely to be linked, at least in part, to instrument operating temperature, as ground-based calibration was performed at a different instrument temperature than is experienced in flight. The fact that no such offset is seen for the $240 \mathrm{GHz}$ receiver again speaks to its greater degree of resilience and stability. Note that the $8 \mathrm{~K}$ radiance difference between measured and expected radiances seen in the line center occurs in an altitude region where radiances near the line center are not used in the $190 \mathrm{GHz}$ retrievals, specifically because they do not convey information on water vapor, as mentioned earlier.

Sideband fractions vary across the spectral region observed (e.g., the $190 \mathrm{GHz}$ lower sideband fractions established in prelaunch calibration vary from $\sim 0.55$ in band 2 to $\sim 0.50$ in band 6 ). By extension, we do not expect the drift in the sideband fraction to have a constant rate across the $190 \mathrm{GHz}$ bands. The analyses of Fig. 12 are only possible in the centers of strong spectral lines, so, in the case of the $190 \mathrm{GHz}$ receiver, we can only obtain information on the fraction at $\sim 8.6 \mathrm{GHz}$ intermediate frequency, the region where the water vapor measurements are made. However, some significant degree of covariation with the drift in other spectral regions in the $190 \mathrm{GHz}$ receiver bandpass can be reasonably expected.

Figure 12 implies a $\sim 1.3 \%$ drift in the sideband fraction in the decade from 2010 through 2019. Figure 13 illustrates the expected impacts (thick lines) of a $1.3 \%$ change in the 


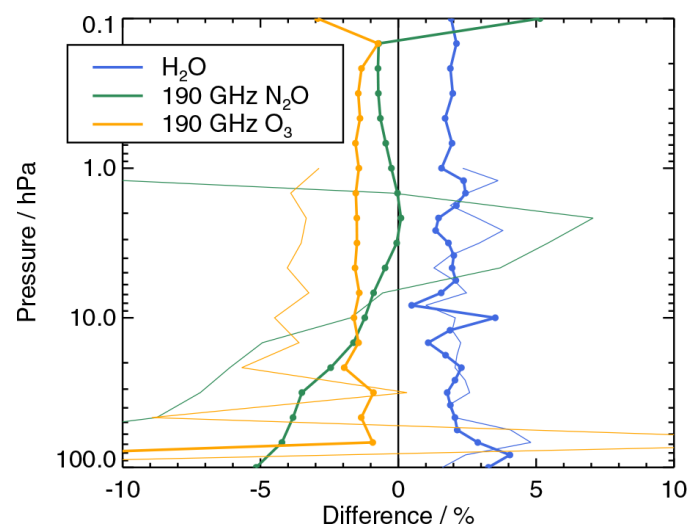

Figure 13. Thick lines with circles show the predicted impact of a $1.3 \%$ change in the $190 \mathrm{GHz}$ sideband fraction on the MLS $\mathrm{H}_{2} \mathrm{O}$ (blue), $190 \mathrm{GHz} \mathrm{N} 2 \mathrm{O}$ (green), and $190 \mathrm{GHz} \mathrm{O}$ (orange) products based on simulated retrievals of a model atmosphere. Thin lines show the corresponding 2010-2019 drift rates. For $\mathrm{H}_{2} \mathrm{O}$ and $\mathrm{N}_{2} \mathrm{O}$, these are taken from $50^{\circ} \mathrm{S}-50^{\circ} \mathrm{N}$ ACE-FTS comparisons, whereas they are taken from comparisons with the MLS $240 \mathrm{GHz}$ "standard product" ozone for $\mathrm{O}_{3}$ (Fig. 7).

$190 \mathrm{GHz}$ sideband fraction (equivalent to a decade's worth of estimated drift) on the $\mathrm{H}_{2} \mathrm{O}, \mathrm{N}_{2} \mathrm{O}$, and $190 \mathrm{GHz} \mathrm{O}_{3}$ products. These results are scaled from the differences between two retrievals of a full day of simulated MLS observations. For one of these simulations, a perturbation has been applied to the $190 \mathrm{GHz}$ sideband fraction; the other is an unperturbed "control" simulation. These simulations are similar to those discussed by Read et al. (2006) but updated for v4. Results are expressed in terms of a percentage of the retrieved value (from the control retrieval).

The simulated changes are generally similar to the drifts reported in the comparisons described in earlier sections (thin lines in Fig. 13), particularly for water vapor in the middle and upper stratosphere. In the case of $190 \mathrm{GHz} \mathrm{O}$ and $\mathrm{N}_{2} \mathrm{O}$, the simulated sideband fraction change impacts underestimate the magnitude of the drift signatures by around a factor of 2. However, the vertical structure of these changes generally agrees with that in the observed drifts in the lower to middle stratosphere, with a strong vertical gradient in the $190 \mathrm{GHz} \mathrm{N} 2 \mathrm{O}$ impacts.

\subsection{The MLS version 5 (v5) algorithms and dataset}

The work to characterize and diagnose the drift in the MLS $190 \mathrm{GHz}$ data products has been the principal focus of the MLS team in developing the algorithms and software for the v5 release of the MLS dataset.

The calculations underlying Fig. 12 have been used to generate new time-dependent sideband fraction calibration information (with monthly granularity) throughout the Aura mission. These evolving sideband fractions include not only the slow time drifts but also the jumps seen earlier in the mis- sion, as well as the $\sim 6.5 \%$ initial offset from the values derived from prelaunch calibrations. In the absence of insights into the sideband fraction beyond the $183 \mathrm{GHz}$ line-center region used for this diagnosis, the same percentage changes are assumed to apply uniformly across the $190 \mathrm{GHz}$ receiver's spectral range. The analysis of Figure 13 indicates that correction of the sideband fraction drift should go a long way toward improving the drift seen between MLS and ACE-FTS $\mathrm{H}_{2} \mathrm{O}$ in the mid-stratosphere to upper stratosphere, but perhaps not the larger ( $\sim 7 \%$ per decade) drifts seen at lower altitudes in midlatitudes nor those seen in comparison to the frost point record.

An additional focus of the v5 development was to alleviate a previously noted (Vömel et al., 2007) significant dry bias in MLS $\mathrm{H}_{2} \mathrm{O}$ in the region below the tropopause in $\mathrm{v} 4$ and all previous versions. The bias is of the order of $20 \%$ in the tropics (but smaller at higher latitudes). The change from the prelaunch value of the $190 \mathrm{GHz}$ sideband fraction increased water vapor in this region by around $10 \%$, somewhat alleviating the bias. Moreover, it was found that, of the various sources of systematic error giving rise to biases in the MLS water vapor observations (Read et al., 2007), another error term with an impact fingerprint that matches that of the observed bias is the vertical pointing offset between the MLS $190 \mathrm{GHz}$ receiver and the nominal boresight pointing (defined as the pointing of "band 8 " in the $240 \mathrm{GHz}$ signals used for retrieving temperature and pressure). Adjusting the vertical pointing offset by $0.0015^{\circ}$ (equivalent to a $70 \mathrm{~m}$ shift in altitude at the limb) further alleviated this bias (the $2 \sigma$ estimated uncertainty in this parameter is $0.003^{\circ}$, based on prelaunch calibration and in-flight observations of the Moon). In addition to improving the $\mathrm{H}_{2} \mathrm{O}$ dry bias below the tropopause, these changes had the encouraging benefit of essentially eliminating the v4 bias between the MLS $190 \mathrm{GHz}$ ozone product and the ozone measured by the 240 and $640 \mathrm{GHz}$ receivers.

Another goal of the MLS v5 development was to reduce the clear high bias in the $190 \mathrm{GHz} \mathrm{N} \mathrm{N}_{2} \mathrm{O}$ product at $100 \mathrm{hPa}$, which rendered it unsuitable for scientific use. Development of a separate retrieval phase (focused on $\mathrm{N}_{2} \mathrm{O}$ ) that changed the way spectral "background" signals were accounted for mitigated that issue. However, it was found that the sideband fraction offset from the prelaunch value implemented as part of the time-varying calibration, as discussed above, significantly increased the $\mathrm{N}_{2} \mathrm{O}$ in the lower stratosphere once again. Accordingly, the $\mathrm{N}_{2} \mathrm{O}$-focused retrieval phase uses a time-dependent sideband fraction that reflects only the drift, not the initial offset from prelaunch measurements. Given the proximity of the $\mathrm{N}_{2} \mathrm{O}$ line to the region where the analysis in Fig. 12 provides insight into the sideband fraction, this inconsistency is clearly unsatisfying and warrants further investigation. However, while the absolute value of lowerstratospheric $\mathrm{N}_{2} \mathrm{O}$ as measured by MLS is subject to some uncertainty, the morphology is expected to be robust. 

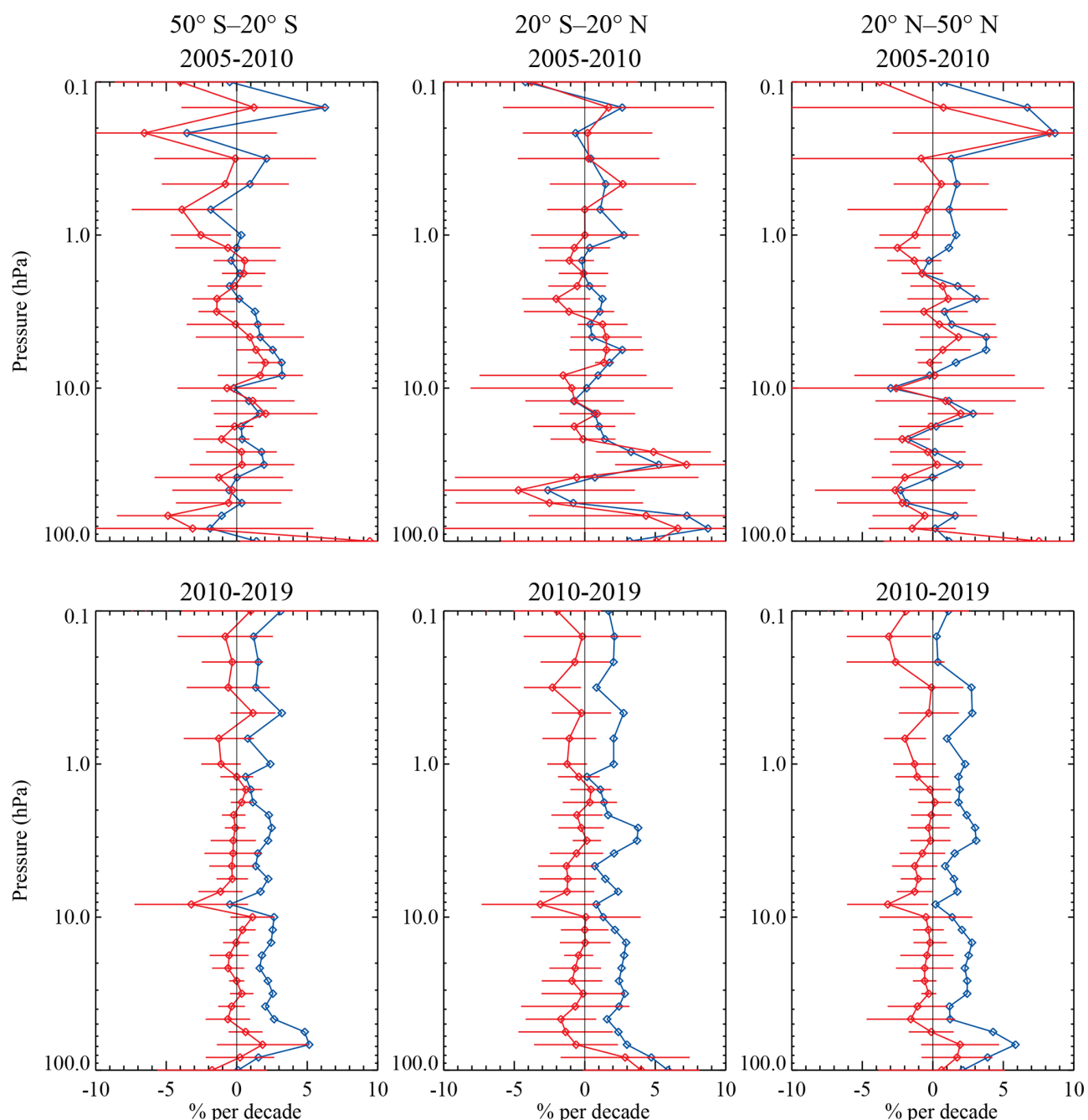

Figure 14. Drifts between MLS water vapor (v5, red, and v4, blue) and ACE-FTS version 4.1 observations. Coincidence criteria (and v4 results) are the same as for Fig. 2, with error bars on $\mathrm{v} 4$ omitted here for clarity.

Table 2. Comparison of MLS v4 and v5 water vapor drifts versus the frost point record. All numbers (apart from those for pressure) are percent per decade. Differences $(\Delta)$ are v4 minus v5.

\begin{tabular}{lrrr|rrr|rrr}
\hline Pressure & \multicolumn{3}{c|}{ Lauder } & \multicolumn{3}{c|}{ Hilo } & \multicolumn{3}{|c}{ Boulder } \\
\cline { 2 - 10 } & v4 & v5 & $\Delta$ & v4 & v5 & $\Delta$ & v4 & v5 & $\Delta$ \\
\hline $22 \mathrm{hPa}$ & 8.5 & 5.0 & 3.5 & 3.4 & 0.5 & 2.9 & 9.8 & 8.4 & 1.4 \\
$46 \mathrm{hPa}$ & 7.5 & 3.8 & 3.7 & 7.1 & 3.5 & 3.6 & 9.1 & 7.5 & 1.6 \\
$68 \mathrm{hPa}$ & 11.3 & 6.2 & 5.0 & 11.2 & 2.1 & 9.1 & 10.4 & 7.9 & 2.6 \\
$100 \mathrm{hPa}$ & 4.0 & 2.4 & 1.7 & 2.1 & 0.2 & 1.9 & 6.5 & 6.0 & 0.5 \\
\hline
\end{tabular}

As a preliminary assessment of drifts in MLS v5, Fig. 14 shows comparisons of ACE-FTS $\mathrm{H}_{2} \mathrm{O}$ with MLS v4 results (repeated from Fig. 2) in blue and with MLS v5 in red. These comparisons indicate that the post-2010 drift in $\mathrm{H}_{2} \mathrm{O}$ has been significantly reduced and is no longer statistically significant at $2 \sigma$ except in the $20-50^{\circ} \mathrm{N}$ band at $6.8 \mathrm{hPa}$ (where it exceeds the $2 \sigma$ envelope by only $\sim 0.3 \%$ per decade). We note that the vertical structure of the $\mathrm{v} 5$ and $\mathrm{v} 4$ drifts are very similar for all regions and time periods and that the overall effect of v5 seems to have been to reduce the post-2010 MLS $\mathrm{H}_{2} \mathrm{O}$ drift by $2 \%-4 \%$ per decade at most pressure levels.

Figure 15 reproduces Fig. 1 using MLS v5 observations, and Table 2 compares the fitted 2010-2019 drifts between the two MLS versions. The Lauder and Hilo sites show similar 


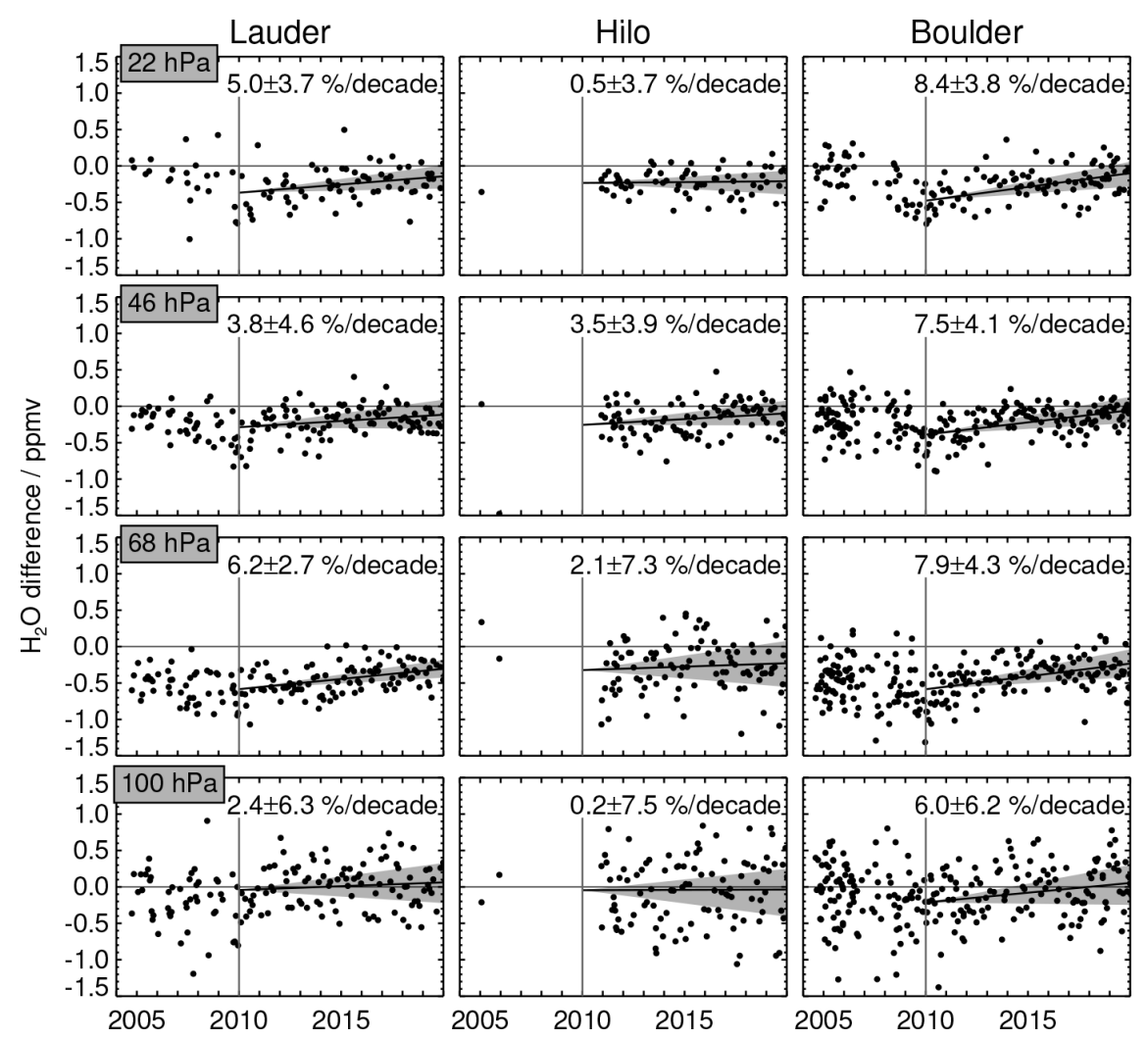

Figure 15. Figure 15 is the same as Fig. 1 but compares MLS v5 water vapor observations to frost point measurements.

reductions in drift at 46 and $22 \mathrm{hPa}$ of around $3 \%$ per decade. These sites show larger drift reductions at $68 \mathrm{hPa}$, as large as $9 \%$ per decade for Hilo, whereas drift reductions at $100 \mathrm{hPa}$ are only $\sim 2 \%$ per decade. In contrast, the drifts in the Boulder comparisons are diminished less, by $0.5 \%$ per decade at $100 \mathrm{hPa}$ and about $1 \%-2 \%$ per decade at higher altitudes.

Broadly speaking, therefore, the drift in water vapor seems to be reduced by about $2 \%-4 \%$ per decade over much of the vertical range, although there is some variation in the degree of reduction with altitude and latitude. Such a reduction is sufficient to place the MLS v5 versus ACE-FTS drifts below the level of statistical significance. The frost point comparisons, having indicated stronger drifts in MLS v4 than seen in ACE-FTS comparisons, continue to indicate statistically significant, although reduced, drifts in the MLS v5 water vapor.

The fact that a statistically significant drift remains between MLS v5 water vapor and the frost point measurements, although no statistically significant drift is seen in comparisons between MLS v5 and ACE-FTS water vapor, is striking and, thus far, unexplained. This is consistent with the notable disparity in MLS v4 drift estimates derived from the frost point and ACE-FTS records (Fig. 1 versus Fig. 2). We note historical challenges associated with quantifying water vapor trends from the Boulder record (Kunz et al., 2013) and some debate surrounding the extent to which water vapor trends over Boulder are representative of trends more broadly (Hegglin et al., 2014; Lossow et al., 2018). However, given that, for Figs. 1 and 15, only MLS profiles in close proximity to the Boulder site are being considered, the issue of Boulder's representativeness should not come into play, as it applies equally to the frost point observations and the MLS observations sampled in that locale, at least to first order.

Figure 16 shows the equivalent comparisons to those in Fig. 14 for $\mathrm{N}_{2} \mathrm{O}$ (with v4 reproduced from Fig. 10). Here, v5 has reduced the magnitude of the drift, which was larger than that for $\mathrm{H}_{2} \mathrm{O}$, particularly at lower altitudes. However, a substantial (as large as $10 \%$ per decade) and statistically significant decreasing drift remains at pressures of $20 \mathrm{hPa}$ and greater. These figures are consistent with the analysis in Fig. 13, which indicates that the expected impact of sideband fraction change, while a good match to the observed drift in water vapor, only accounts for about half of the observed $\mathrm{N}_{2} \mathrm{O}$ drift.

\section{Summary and guidance for users of $\mathrm{MLS}_{2} \mathrm{O}$ and $\mathrm{N}_{2} \mathrm{O}$ observations}

It is clear that the MLS v4 water vapor product is subject to a slow positive drift, likely starting around 2010. A $2 \%-7 \%$ per decade drift is seen in comparisons with ACE-FTS v4.1, 

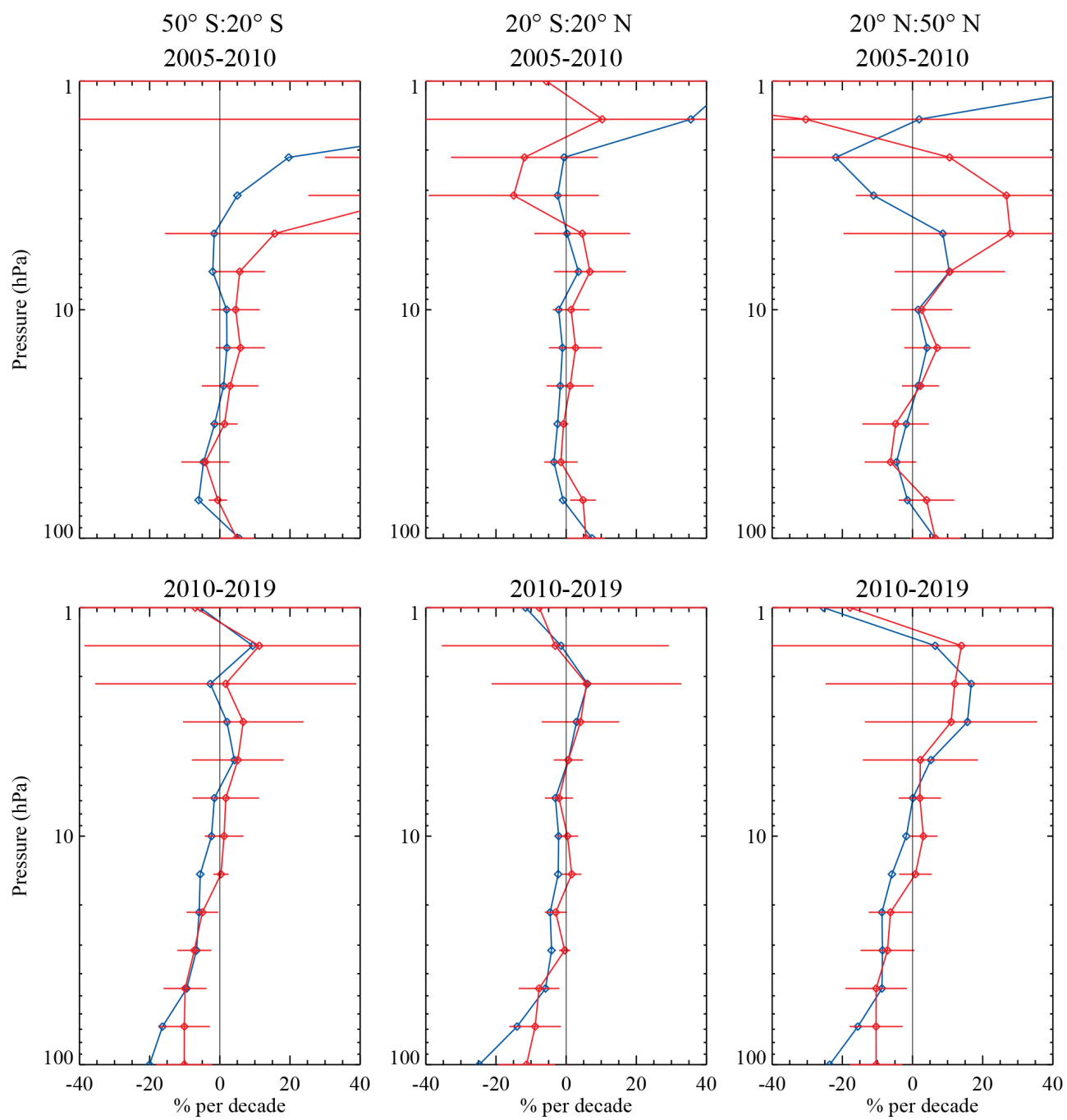

Figure 16. Figure 16 is the same as Fig. 14 but for $\mathrm{N}_{2} \mathrm{O}$.

with the largest drifts between 100 and $46 \mathrm{hPa}$. Comparisons with balloon-borne frost point hygrometers indicate a larger $\sim 10 \%$ per decade drift at these levels. Drifts are also seen in measurements of $\mathrm{N}_{2} \mathrm{O}$ and $\mathrm{O}_{3}$ from the same MLS $190 \mathrm{GHz}$ subsystem used to measure $\mathrm{H}_{2} \mathrm{O}$. Detailed study of the MLS $190 \mathrm{GHz}$ radiances reveals a drift (and post-launch offset) in the sideband fractions of around $1.3 \%$ over the last decade that accounts for a significant fraction of the observed drift between MLS and other sensors, with the remainder likely due to other symptoms of an aging receiver. Drifts in the $190 \mathrm{GHz}$ sideband fractions will also impact the MLS HCN product and the MLS $\mathrm{HNO}_{3}$ product for pressures smaller than $22 \mathrm{hPa}$. However, no clear signals of such drifts are seen in comparisons to ACE-FTS.

While the existence of such a drift is clearly unfortunate, we note that it did not start to appear until around 6 years into MLS in-orbit operations, which corresponds to the original design life of the instrument (now more than 17 years into a nominal 5-year mission). Further, the analyses described above developed to characterize and understand this drift have had the additional benefit of underscoring the stability of the other MLS receivers at 118, 240, and $640 \mathrm{GHz}$. We emphasize that this drift does not affect the $\mathrm{MLS} \mathrm{O}_{3}, \mathrm{CO}, \mathrm{ClO}$, $\mathrm{HCl}, \mathrm{HOCl}, \mathrm{CH}_{3} \mathrm{Cl}, \mathrm{CH}_{3} \mathrm{CN}, \mathrm{CH}_{3} \mathrm{OH}, \mathrm{BrO}, \mathrm{HO}_{2}, \mathrm{OH}, \mathrm{SO}_{2}$, temperature, geopotential height, or cloud ice, standard products. We further note that this drift does not call into question the fundamental stability of the microwave limb sounding approach in general.

Data from the entire MLS mission have been reprocessed with the new v5 algorithms, and preliminary comparisons to ACE-FTS v4.1 show a reduction of about $2 \%-4 \%$ per decade in the $\mathrm{H}_{2} \mathrm{O}$ drifts. As a result, no statistically significant drift between MLS v5 $\mathrm{H}_{2} \mathrm{O}$ and ACE-FTS observations is seen. Drifts in comparisons of MLS v5 $\mathrm{H}_{2} \mathrm{O}$ to frost point measurements are reduced compared with those in $\mathrm{v} 4$ but are still statistically significant. For $\mathrm{N}_{2} \mathrm{O}$, statistically significant 
drifts remain between MLS v5 and ACE-FTS, although they are reduced to about half the magnitude of those seen for MLS v4.

Scientists are strongly advised to use MLS v5 data in preference to $\mathrm{v} 4$ for all products, particularly for $\mathrm{H}_{2} \mathrm{O}, \mathrm{N}_{2} \mathrm{O}$, $\mathrm{HCN}$, and $\mathrm{HNO}_{3}$, in light of the work to correct the offsets and drift in the MLS $190 \mathrm{GHz}$ receiver calibration. Users are still advised to apply caution when interpreting the temporal changes in $v 5 \mathrm{H}_{2} \mathrm{O}, \mathrm{N}_{2} \mathrm{O}, \mathrm{HCN}$, and $\mathrm{HNO}_{3}$ on multiyear timescales, including long-term trends, and to undertake such studies only in close consultation with the MLS team. On the other hand, studies of spatial and seasonal to annual variability in these products, and investigations such as the speed of the "tape recorder" (Mote et al., 1995, 1996) and the impact of the quasi-biennial oscillation, should be largely unaffected. The MLS team is planning to continue processing incoming data with both the $\mathrm{v} 4$ and $\mathrm{v} 5$ algorithms for the foreseeable future, as continued comparisons between the two versions provide information on the evolution of the drift and its correction.

Data availability. MLS data are available at the NASA GSFC DISC (https://disc.gsfc.nasa.gov, Livesey et al., 2020). Frost point sonde data can be obtained from NOAA (https://gml.noaa. gov/ozwv/wvap/, Hall et al., 2016). ACE-FTS observations are available, following registration, from http://www.ace.uwaterloo.ca (Bernath et al., 2005), with the data quality information available at https://doi.org/10.5683/SP2/BC4ATC (Sheese and Walker, 2020; Sheese et al., 2015). The SABER water vapor data are available at http://saber.gats-inc.com/ (Rong et al., 2019), and ground-based microwave observations are archived at https://www-air.larc.nasa.gov/ missions/ndacc/data.html (Nedoluha et al., 2011).

Author contributions. NJL oversaw the MLS project and wrote much of the text. WGR led the investigation into the MLS $190 \mathrm{GHz}$ drifts and the development of the MLS v5 algorithms. LF led the analysis related to the MLS ozone products and much of the analysis for nitrous oxide. AL performed the comparisons to ACE-FTS and SABER and led the microphysical studies. MLS contributed to the microphysical studies. MJS and LFM, along with all of the aforementioned authors, contributed to the investigation of the drifts and development and testing of the v5 algorithms. RFJ provided insights in his role as MLS instrument scientist. PAW led the implementation of the MLS v5 algorithms and testing of the associated software. DFH contributed data and guidance for the frost point measurements, with KAW and PES similarly contributing for ACE-FTS, and GEN for the ground-based microwave. All authors provided extensive comments and guidance on the paper.

Competing interests. The contact author has declared that neither they nor their co-authors have any competing interests.
Disclaimer. Publisher's note: Copernicus Publications remains neutral with regard to jurisdictional claims in published maps and institutional affiliations.

Acknowledgements. We thank James Russell III and Pingping Rong of Hampton University for making the SABER $\mathrm{H}_{2} \mathrm{O}$ record available and for helpful comments on this paper. We thank the handling editor, Rolf Müller, for his helpful suggestions on the initially submitted version of this article. We also thank the two anonymous reviewers and Quentin Errera for their comments, which further improved the paper. The research carried out at the Jet Propulsion Laboratory, California Institute of Technology, was performed under a contract with the National Aeronautics and Space Administration. The Atmospheric Chemistry Experiment is a Canadian-led mission mainly supported by the CSA. Gerald E. Nedoluha was funded by NASA under the Upper Atmosphere Research Program and by the Office of Naval Research.

Financial support. This research has been supported by the National Aeronautics and Space Administration (grant no. 80NM0018D0004).

Review statement. This paper was edited by Rolf Müller and reviewed by two anonymous referees.

\section{References}

Adams, C., Bourassa, A. E., Sofieva, V., Froidevaux, L., McLinden, C. A., Hubert, D., Lambert, J.-C., Sioris, C. E., and Degenstein, D. A.: Assessment of Odin-OSIRIS ozone measurements from 2001 to the present using MLS, GOMOS, and ozonesondes, Atmos. Meas. Tech., 7, 49-64, https://doi.org/10.5194/amt-7-492014, 2014.

Ball, W. T., Alsing, J., Mortlock, D. J., Staehelin, J., Haigh, J. D., Peter, T., Tummon, F., Stübi, R., Stenke, A., Anderson, J., Bourassa, A., Davis, S. M., Degenstein, D., Frith, S., Froidevaux, L., Roth, C., Sofieva, V., Wang, R., Wild, J., Yu, P., Ziemke, J. R., and Rozanov, E. V.: Evidence for a continuous decline in lower stratospheric ozone offsetting ozone layer recovery, Atmos. Chem. Phys., 18, 1379-1394, https://doi.org/10.5194/acp18-1379-2018, 2018.

Ball, W. T., Rozanov, E. V., Alsing, J., Marsh, D. R., Tummon, F., Mortlock, D. J., Kinnison, D., and Haigh, J. D.: The Upper Stratospheric Solar Cycle Ozone Response, Geophys. Res. Lett., 46, 1831-1841, https://doi.org/10.1029/2018g1081501, 2019.

Bernath, P. F., McElroy, C. T., Abrams, M. C., Boone, C. D., Butler, M., Camy-Peyret, C., Carleer, M., Clerbaux, C., Coheur, P.-F., Colin, R., DeCola, P., DeMazière, M., Drummond, J. R., Dufour, D., Evans, W. F. J., Fast, H., Fussen, D., Gilbert, K., Jennings, D. E., Llewellyn, E. J., Lowe, R. P., Mahieu, E., McConnell, J. C., McHugh, M., McLeod, S. D., Michaud, R., Midwinter, C., Nassar, R., Nichitiu, F., Nowlan, C., Rinsland, C. P., Rochon, Y. J., Rowlands, N., Semeniuk, K., Simon, P., Skelton, R., Sloan, J. J., Soucy, M.-A., Strong, K., Tremblay, P., Turnbull, D., Walker, K. A., Walkty, I., Wardle, D. A., Wehrle, 
V., Zander, R., and Zou, J.: Atmospheric Chemistry Experiment (ACE): Mission overview, Geophys. Res. Lett., 32, L15S01, https://doi.org/10.1029/2005GL022386, 2005 (data available at: http://www.ace.uwaterloo.ca, last access: 29 September 2021).

Chipperfield, M. P., Dhomse, S., Hossaini, R., Feng, W., Santee, M. L., Weber, M., Burrows, J. P., Wild, J. D., Loyola, D., and Coldewey-Egbers, M.: On the Cause of Recent Variations in Lower Stratospheric Ozone, Geophys. Res. Lett., 45, 5718-5726, https://doi.org/10.1029/2018g1078071, 2018.

Dessler, A. E., Schoeberl, M. R., Wang, T., Davis, S. M., Rosenlof, K. H., and Vernier, J. P.: Variations of stratospheric water vapor over the past three decades, J. Geophys. Res., 119, 12,588, https://doi.org/10.1002/2014JD021712, 2014.

Diallo, M., Konopka, P., Santee, M. L., Müller, R., Tao, M., Walker, K. A., Legras, B., Riese, M., Ern, M., and Ploeger, F.: Structural changes in the shallow and transition branch of the BrewerDobson circulation induced by El Niño, Atmos. Chem. Phys., 19, 425-446, https://doi.org/10.5194/acp-19-425-2019, 2019.

Eckert, E., von Clarmann, T., Kiefer, M., Stiller, G. P., Lossow, S., Glatthor, N., Degenstein, D. A., Froidevaux, L., GodinBeekmann, S., Leblanc, T., McDermid, S., Pastel, M., Steinbrecht, W., Swart, D. P. J., Walker, K. A., and Bernath, P. F.: Drift-corrected trends and periodic variations in MIPAS IMK/IAA ozone measurements, Atmos. Chem. Phys., 14, 25712589, https://doi.org/10.5194/acp-14-2571-2014, 2014.

Errera, Q., Chabrillat, S., Christophe, Y., Debosscher, J., Hubert, D., Lahoz, W., Santee, M. L., Shiotani, M., Skachko, S., von Clarmann, T., and Walker, K.: Technical note: Reanalysis of Aura MLS chemical observations, Atmos. Chem. Phys., 19, 1364713679, https://doi.org/10.5194/acp-19-13647-2019, 2019.

Fischer, H., Birk, M., Blom, C., Carli, B., Carlotti, M., von Clarmann, T., Delbouille, L., Dudhia, A., Ehhalt, D., Endemann, M., Flaud, J. M., Gessner, R., Kleinert, A., Koopman, R., Langen, J., López-Puertas, M., Mosner, P., Nett, H., Oelhaf, H., Perron, G., Remedios, J., Ridolfi, M., Stiller, G., and Zander, R.: MIPAS: an instrument for atmospheric and climate research, Atmos. Chem. Phys., 8, 2151-2188, https://doi.org/10.5194/acp-8-21512008, 2008.

Froidevaux, L., Jiang, Y. B., Lambert, A., Livesey, N. J., Read, W. G., Waters, J. W., Browell, E. V., Hair, J. W., Avery, M. A., McGee, T. J., Twigg, L. W., Sumnicht, G. K., Jucks, K. W., Margitan, J. J., Sen, B., Stachnik, R. A., Toon, G. C., Bernath, P. F., Boone, C. D., Walker, K. A., Filipiak, M. J., Harwood, R. S., Fuller, R. A., Manney, G. L., Schwartz, M. J., Daffer, W. H., Drouin, B. J., Cofield, R. E., Cuddy, D. T., Jarnot, R. F., Knosp, B. W., Perun, V. S., Snyder, W. V., Stek, P. C., Thurstans, R. P., and Wagner, P. A.: Validation of Aura Microwave Limb Sounder stratospheric and mesospheric ozone measurements, J. Geophys. Res., 113, D15S20, https://doi.org/10.1029/2007JD008771, 2008.

Froidevaux, L., Kinnison, D. E., Wang, R., Anderson, J., and Fuller, R. A.: Evaluation of CESM1 (WACCM) free-running and specified dynamics atmospheric composition simulations using global multispecies satellite data records, Atmos. Chem. Phys., 19, 4783-4821, https://doi.org/10.5194/acp-19-4783-2019, 2019.

Gaudel, A., Cooper, O. R., Ancellet, G., Barret, B., Boynard, A., Burrows, J. P., Clerbaux, C., Coheur, P.-F., Cuesta, J., Cuevas, E., Doniki, S., Dufour, G., Ebojie, F., Foret, G., Garcia, O., Granados-Muñoz, M. J., Hannigan, J. W., Hase, F.,
Hassler, B., Huang, G., Hurtmans, D., Jaffe, D., Jones, N., Kalabokas, P., Kerridge, B., Kulawik, S., Latter, B., Leblanc, T., Flochmoë, E. L., Lin, W., Liu, J., Liu, X., Mahieu, E., McClure-Begley, A., Neu, J. L., Osman, M., Palm, M., Petetin, H., Petropavlovskikh, I., Querel, R., Rahpoe, N., Rozanov, A., Schultz, M. G., Schwab, J., Siddans, R., Smale, D., Steinbacher, M., Tanimoto, H., Tarasick, D. W., Thouret, V., Thompson, A. M., Trickl, T., Weatherhead, E., Wespes, C., Worden, H. M., Vigouroux, C., Xu, X., Zeng, G., and Ziemke, J.: Tropospheric Ozone Assessment Report: Present-day distribution and trends of tropospheric ozone relevant to climate and global atmospheric chemistry model evaluation, Elem. Sci. Anth., 6, 39, https://doi.org/10.1525/elementa.291, 2018.

Hall, E. G., Jordan, A. F., Hurst, D. F., Oltmans, S. J., Vömel, H., Kühnreich, B., and Ebert, V.: Advancements, measurement uncertainties, and recent comparisons of the NOAA frost point hygrometer, Atmos. Meas. Tech., 9, 4295-4310, https://doi.org/10.5194/amt-9-4295-2016, 2016 (data available at: https://gml.noaa.gov/ozwv/wvap/, last access: 29 September 2021).

Han, Y., Tian, W., Chipperfield, M. P., Zhang, J., Wang, F., Sang, W., Luo, J., Feng, W., Chrysanthou, A., and Tian, H.: Attribution of the Hemispheric Asymmetries in Trends of Stratospheric Trace Gases Inferred from Microwave Limb Sounder (MLS) Measurements, J. Geophys. Res., 124, 6283-6293, https://doi.org/10.1029/2018jd029723, 2019.

Hegglin, M. I., Plummer, D. A., Shepherd, T. G., Scinocca, J. F., Anderson, J., Froidevaux, L., Funke, B., Hurst, D., Rozanov, A., Urban, J., von Clarmann, T., Walker, K. A., Wang, H. J., Tegtmeier, S., and Weigel, K.: Vertical structure of stratospheric water vapour trends derived from merged satellite data, Nat. Geosci., 7, 768-776, https://doi.org/10.1038/NGEO2236, 2014.

Hubert, D., Lambert, J.-C., Verhoelst, T., Granville, J., Keppens, A., Baray, J.-L., Bourassa, A. E., Cortesi, U., Degenstein, D. A., Froidevaux, L., Godin-Beekmann, S., Hoppel, K. W., Johnson, B. J., Kyrölä, E., Leblanc, T., Lichtenberg, G., Marchand, M., McElroy, C. T., Murtagh, D., Nakane, H., Portafaix, T., Querel, R., Russell III, J. M., Salvador, J., Smit, H. G. J., Stebel, K., Steinbrecht, W., Strawbridge, K. B., Stübi, R., Swart, D. P. J., Taha, G., Tarasick, D. W., Thompson, A. M., Urban, J., van Gijsel, J. A. E., Van Malderen, R., von der Gathen, P., Walker, K. A., Wolfram, E., and Zawodny, J. M.: Ground-based assessment of the bias and long-term stability of 14 limb and occultation ozone profile data records, Atmos. Meas. Tech., 9, 2497-2534, https://doi.org/10.5194/amt-9-2497-2016, 2016.

Hurst, D. F., Oltmans, S. J., Vömel, H., Rosenlof, K. H., Davis, S. M., Ray, E. A., Hall, E. G., and Jordan, A. F.: Stratospheric water vapor trends over Boulder, Colorado: Analysis of the 30 year Boulder record, J. Geophys. Res., 116, D02306, https://doi.org/10.1029/2010jd015065, 2011.

Hurst, D. F., Lambert, A., Read, W. G., Davis, S. M., Rosenlof, K. H., Hall, E. G., Jordan, A. F., and Oltmans, S. J.: Validation of Aura Microwave Limb Sounder stratospheric water vapor measurements by the NOAA frost point hygrometer, J. Geophys. Res., 119, 1612-1625, https://doi.org/10.1002/2013jd020757, 2014.

Hurst, D. F., Read, W. G., Vömel, H., Selkirk, H. B., Rosenlof, K. H., Davis, S. M., Hall, E. G., Jordan, A. F., and Oltmans, S. J.: Recent divergences in stratospheric water vapor 
measurements by frost point hygrometers and the Aura $\mathrm{Mi}$ crowave Limb Sounder, Atmos. Meas. Tech., 9, 4447-4457, https://doi.org/10.5194/amt-9-4447-2016, 2016.

Jarnot, R. F., Perun, V. S., and Schwartz, M. J.: Radiometric and Spectral Performance and Calibration of the GHz Bands of EOS MLS, IEEE Trans. Geosci. Remote Sens., 44, 1131-1143, 2006.

Jiang, Y. B., Froidevaux, L., Lambert, A., Livesey, N. J., Read, W. G., Waters, J. W., Bojkov, B., Leblanc, T., McDermid, I. S., Godin-Beekmann, S., Filipiak, M. J., Harwood, R. S., Fuller, R. A., Daffer, W. H., Drouin, B. J., Cofield, R. E., Cuddy, D. T., Jarnot, R. F., Knosp, B. W., Perun, V. S., Schwartz, M. J., Snyder, W. V., Stek, P. C., Thurstans, R. P., Wagner, P. A., Allaart, M., Andersen, S. B., Bodeker, G., Calpini, B., Claude, H., Coetzee, G., Davies, J., De Backer, H., Dier, H., Fujiwara, M., Johnson, B., Kelder, H., Leme, N. P., Koenig-Langlo, G., Kyro, E., Laneve, G., Fook, L. S., Merrill, J., Morris, G., Newchurch, M., Oltmans, S., Parrondos, M. C., Posny, F., Schmidlin, F., Skrivankova, P., Stubi, R., Tarasick, D., Thompson, A., Thouret, V., Viatte, P., Vomel, H., von Der Gathen, P., Yela, M., and Zablocki, G.: Validation of the Aura Microwave Limb Sounder Ozone by Ozonesonde and Lidar Measurements, J. Geophys. Res., 112, D24S34, https://doi.org/10.1029/2007JD008776, 2007.

Kunz, A., Müller, R., Homonnai, V., M. Jánosi, I., Hurst, D., Rap, A., M. Forster, P., Rohrer, F., Spelten, N., and Riese, M.: Extending water vapor trend observations over Boulder into the tropopause region: Trend uncertainties and resulting radiative forcing, J. Geophys. Res., 118, 11269-11284, https://doi.org/10.1002/jgrd.50831, 2013.

Lambert, A. and Santee, M. L.: Accuracy and precision of polar lower stratospheric temperatures from reanalyses evaluated from A-Train CALIOP and MLS, COSMIC GPS RO, and the equilibrium thermodynamics of supercooled ternary solutions and ice clouds, Atmos. Chem. Phys., 18, 1945-1975, https://doi.org/10.5194/acp-18-1945-2018, 2018.

Livesey, N. J., Snyder, W. V., Read, W. G., and Wagner, P. A.: Retrieval algorithms for the EOS Microwave Limb Sounder (MLS), IEEE Trans. Geosci. Remote Sens., 44, 1144-1155, https://doi.org/10.1109/TGRS.2006.872327, 2006.

Livesey, N. J., Read, W. G., Wagner, P. A., Froidevaux, L., Lambert, A., Manney, G. L., Valle, L. F. M., Pumphrey, H. C., Santee, M. L., Schwartz, M. J., Wang, S., Fuller, R. A., Jarnot, R. F., Knosp, B. W., Martinez, E., and Lay, R. R.: EOS MLS Version 4.2x Level 2 data quality and description document (Revision E), Tech. Rep., Jet Propulsion Laboratory, available at: https://mls. jpl.nasa.gov/eos-aura-mls/data-documentation (last access: 29 September, 2021), 2020 (data available at: https://disc.gsfc.nasa. gov, last access: 29 September 2021).

Long, C. S., Fujiwara, M., Davis, S., Mitchell, D. M., and Wright, C. J.: Climatology and interannual variability of dynamic variables in multiple reanalyses evaluated by the SPARC Reanalysis Intercomparison Project (S-RIP), Atmos. Chem. Phys., 17, 1459314629, https://doi.org/10.5194/acp-17-14593-2017, 2017.

Lossow, S., Hurst, D. F., Rosenlof, K. H., Stiller, G. P., von Clarmann, T., Brinkop, S., Dameris, M., Jöckel, P., Kinnison, D. E., Plieninger, J., Plummer, D. A., Ploeger, F., Read, W. G., Remsberg, E. E., Russell, J. M., and Tao, M.: Trend differences in lower stratospheric water vapour between Boulder and the zonal mean and their role in understanding fundamental ob- servational discrepancies, Atmos. Chem. Phys., 18, 8331-8351, https://doi.org/10.5194/acp-18-8331-2018, 2018.

Mastenbrook, H. J. and Oltmans, S. J.: Stratospheric Water Vapor Variability for Washington, DC/Boulder, CO: 1964-82, J. Atmos. Sci., 40, 2157—-2165, https://doi.org/10.1175/15200469(1983)040<2157:swvvfw>2.0.co;2, 1983.

Mote, P. W., Rosenlof, K. H., Holton, J. R., Harwood, R. S., and Waters, J. W.: Seasonal variation of water vapour in the tropical lower stratosphere, Geophys. Res. Lett., 22, 1093-1096, 1995.

Mote, P. W., Rosenlof, K. H., McIntyre, M. E., Carr, E. S., Holton, J. R., Kinnersley, J. S., Pumphrey, H. C., Russell III, J. M., Waters, J. W., , and Gille, J. C.: An atmospheric tape recorder: The imprint of tropical tropopause temperatures on stratospheric water vapor, J. Geophys. Res., 101, 3989-4006, https://doi.org/10.1029/95JD03422, 1996.

Murtagh, D., Frisk, U., Merino, F., Ridal, M., Jonsson, A., Stegman, J., Witt, G., Eriksson, P., Jimenez, C., Mégie, G., de La Noëë, J., Ricaud, P., Baron, P., Pardo, J.-R., Hauchecorne, A., Llewellyn, E. J., Degenstein, D. A., Gattinger, R. L., Lloyd, N. D., Evans, W. F. J., McDade, I. C., Haley, C., Sioris, C., von Savigny, C., Solheim, B. H., McConnell, J. C., Strong, K., Richardson, E. H., Leppelmeier, G. W., Kyrölä, E., Auvinen, H., and Oikarinen, L.: An overview of the Odin atmospheric mission, Can. J. Phys., 80, 309-319, https://doi.org/10.1139/p01-157, 2002.

Nair, P. J., Godin-Beekmann, S., Froidevaux, L., Flynn, L. E., Zawodny, J. M., Russell III, J. M., Pazmiño, A., Ancellet, G., Steinbrecht, W., Claude, H., Leblanc, T., McDermid, S., van Gijsel, J. A. E., Johnson, B., Thomas, A., Hubert, D., Lambert, J.-C., Nakane, H., and Swart, D. P. J.: Relative drifts and stability of satellite and ground-based stratospheric ozone profiles at NDACC lidar stations, Atmos. Meas. Tech., 5, 1301-1318, https://doi.org/10.5194/amt-5-1301-2012, 2012.

Nedoluha, G. E., Gomez, R. M., Hicks, B. C., Helmboldt, J., Bevilacqua, R. M., and Lambert, A.: Ground-based microwave measurements of water vapor from the midstratosphere to the mesosphere, J. Geophys. Res., 116, D02309, https://doi.org/10.1029/2010jd014728, 2011 (data available at: https://www-air.larc.nasa.gov/missions/ndacc/data.html, last access: 29 September 2021).

Neu, J. L., Flury, T., Manney, G. L., Santee, M. L., Livesey, N. J., and Worden, J. R.: Tropospheric ozone variations governed by changes in stratospheric circulation, Nat. Geosci., 7, 340-344, https://doi.org/10.1038/ngeo2138, 2014.

Petropavlovskikh, I., Godin-Beekmann, S., Hubert, D., Damadeo, R., Hassler, B., and Sofieva, V.: SPARC/IO3C/GAW Report on Long-term Ozone Trends and Uncertainties in the Stratosphere, Tech. Rep., SPARC, https://doi.org/10.17874/F899E57A20B, 2019.

Randel, W. and Park, M.: Diagnosing Observed Stratospheric Water Vapor Relationships to the Cold Point Tropical Tropopause, J. Geophys. Res., 124, 7018-7033, https://doi.org/10.1029/2019jd030648, 2019.

Read, W. G., Shippony, Z., Schwartz, M. J., Livesey, N. J., and Snyder, W. V.: The clear-sky unpolarized forward model for the EOS Microwave Limb Sounder (MLS), IEEE Trans. Geosci. Remote Sens., 44, 1367-1379, https://doi.org/10.1109/TGRS.2006.873233, 2006.

Read, W. G., Lambert, A., Bacmeister, J., Cofield, R. E., Cuddy, D. T., Daffer, W. H., Drouin, B. J., Fetzer, E., Froidevaux, L., 
Fuller, R., Herman, R., Jarnot, R. F., Jiang, J. H., Jiang, Y. B., Kelly, K., Knosp, B. W., Kovalenko, L. J., Livesey, N. J., Liu, H.-C., Manney, G. L., Miller, D., Mills, B. J., Pickett, H. M., Pumphrey, H. C., Rosenlof, K. H., Sabounchi, X., Santee, M. L., Schwartz, M. J., Snyder, W. V., Stek, P. C., Su, H., Takacs, L. L., Thurstans, R. P., Vömel, H., Wagner, P. A., Waters, J. W., Webster, C. R., Weinstock, E. M., and Wu, D. L.: EOS Aura Microwave Limb Sounder Upper Tropospheric and Lower Stratospheric Humidity Validation, J. Geophys. Res., 112, D24S35, https://doi.org/10.1029/2007JD008752, 2007.

Read, W. G., Schwartz, M. J., Lambert, A., Su, H., Livesey, N. J., Daffer, W. H., and Boone, C. D.: The roles of convection, extratropical mixing, and in-situ freeze-drying in the Tropical Tropopause Layer, Atmos. Chem. Phys., 8, 6051-6067, https://doi.org/10.5194/acp-8-6051-2008, 2008.

Rong, P., Russell, J. M., Marshall, B. T., Gordley, L. L., Mlynczak, M. G., and Walker, K. A.: Validation of water vapor measured by SABER on the TIMED satellite, J. Atmos. Solar-Terr. Phys., 194, 105099, https://doi.org/10.1016/j.jastp.2019.105099, 2019 (data available at: http://saber.gats-inc.com/, last access: 29 September 2021).

Ruiz, D. J., Prather, M. J., Strahan, S. E., Thompson, R. L., Froidevaux, L., and Steenrod, S. D.: How Atmospheric Chemistry and Transport Drive Surface Variability of $\mathrm{N}_{2} \mathrm{O}$ and CFC-11, J. Geophys. Res., 126, e2020JD033979, https://doi.org/10.1029/2020jd033979, 2021.

Schoeberl, M. R., Hilsenrath, A. R. D. E., Bhartia, P. K., Beer, R., Waters, J. W., Gunson, M. R., Froidevaux, L., Gille, J. C., Barnett, J. J., Levelt, P. F., and DeCola, P.: Overview of the EOS Aura mission, IEEE Trans. Geosci. Remote Sens., 44, 10661074, 2006.

Schwartz, M. J., Read, W. G., and Snyder, W. V.: Polarized radiative transfer for Zeeman-split oxygen lines in the EOS MLS forward model, IEEE Trans. Geosci. Remote Sens., 44, 1182-1190, 2006.

Sheese, P. and Walker, K.: Data Quality Flags for ACE-FTS Level 2 Version 4.1/4.2 Data Set, Scholars Portal Dataverse [data set], V10, https://doi.org/10.5683/SP2/BC4ATC, 2020.

Sheese, P. E., Boone, C. D., and Walker, K. A.: Detecting physically unrealistic outliers in ACE-FTS atmospheric measurements, Atmos. Meas. Tech., 8, 741-750, https://doi.org/10.5194/amt-8741-2015, 2015.

Steinbrecht, W., Froidevaux, L., Fuller, R., Wang, R., Anderson, J., Roth, C., Bourassa, A., Degenstein, D., Damadeo, R., Zawodny, J., Frith, S., McPeters, R., Bhartia, P., Wild, J., Long, C., Davis, S., Rosenlof, K., Sofieva, V., Walker, K., Rahpoe, N., Rozanov, A., Weber, M., Laeng, A., von Clarmann, T., Stiller, G., Kramarova, N., Godin-Beekmann, S., Leblanc, T., Querel, R., Swart, D., Boyd, I., Hocke, K., Kämpfer, N., Maillard Barras, E., Moreira, L., Nedoluha, G., Vigouroux, C., Blumenstock, T., Schneider, M., García, O., Jones, N., Mahieu, E., Smale, D., Kotkamp, M., Robinson, J., Petropavlovskikh, I., Harris, N., Hassler, B., Hubert, D., and Tummon, F.: An update on ozone profile trends for the period 2000 to 2016, Atmos. Chem. Phys., 17, 1067510690, https://doi.org/10.5194/acp-17-10675-2017, 2017.

Stolarski, R. S., Douglass, A. R., and Strahan, S. E.: Using satellite measurements of $\mathrm{N}_{2} \mathrm{O}$ to remove dynamical variability from $\mathrm{HCl}$ measurements, Atmos. Chem. Phys., 18, 5691-5697, https://doi.org/10.5194/acp-18-5691-2018, 2018.
Strahan, S. E. and Douglass, A. R.: Decline in Antarctic Ozone Depletion and Lower Stratospheric Chlorine Determined From Aura Microwave Limb Sounder Observations, Geophys. Res. Lett., 45, 382-390, https://doi.org/10.1002/2017g1074830, 2018.

Verstraeten, W. W., Neu, J. L., Williams, J. E., Bowman, K. W., Worden, J. R., and Boersma, K. F.: Rapid increases in tropospheric ozone production and export from China, Nat. Geosci., 8, 690-695, https://doi.org/10.1038/ngeo2493, 2015.

Vömel, H., David, D. E., and Smith, K.: Accuracy of tropospheric and stratospheric water vapor measurements by the cryogenic frost point hygrometer: Instrumental details and observations, J. Geophys. Res., 112, D08305, https://doi.org/10.1029/2006jd007224, 2007.

Vömel, H., Forno, J. E. B. R. N., Fujiwara, M., Hasebe, F., Iwasaki, S., Kivi, R., Komala, N., Kryö, E., Leblanc, T., Morel, B., Ogino, S. Y., Read, W. G., Ryan, S. C., Saraspriya, S., Selkirk, H., Shiotani, M., Canossa, K. V., and Whiteman, D. N.: Validation of Aura Microwave Limb Sounder water vapor by balloon-borne Cryogenic Frost point Hydrometer measurements, J. Geophys. Res., 112, D24S37, https://doi.org/10.1029/2007JD008698, 2007.

Vömel, H., Naebert, T., Dirksen, R., and Sommer, M.: An update on the uncertainties of water vapor measurements using cryogenic frost point hygrometers, Atmos. Meas. Tech., 9, 37553768, https://doi.org/10.5194/amt-9-3755-2016, 2016.

Waters, J. W., Froidevaux, L., Harwood, R. S., Jarnot, R. F., Pickett, H. M., Read, W. G., Siegel, P. H., Cofield, R. E., Filipiak, M. J., Flower, D. A., Holden, J. R., Lau, G. K., Livesey, N. J., Manney, G. L., Pumphrey, H. C., Santee, M. L., Wu, D. L., Cuddy, D. T., Lay, R. R., Loo, M. S., Perun., V. S., Schwartz, M. J., Stek, P. C., Thurstans, R. P., Chandra, K. M., Chavez, M. C., Chen, G., Boyles, M. A., Chudasama, B. V., Dodge, R., Fuller, R. A., Girard, M. A., Jiang, J. H., Jiang, Y., Knosp, B. W., LaBelle, R. C., Lam, J. C., Lee, K. A., Miller, D., Oswald, J. E., Patel, N. C., Pukala, D. M., Quintero, O., Scaff, D. M., Snyder, W. V., Tope, M. C., Wagner, P. A., and Walch, M. J.: The Earth Observing System Microwave Limb Sounder (EOS MLS) on the Aura satellite, IEEE Trans. Geosci. Remote Sens., 44, 10751092, https://doi.org/10.1109/TGRS.2006.873771, 2006.

Weinstock, E. M., Smith, J. B., Sayres, D. S., Pittman, J. V., Spackman, J. R., Hintsa, E. J., Hanisco, T. F., Moyer, E. J., St. Clair, J. M., Sargent, M. R., and Anderson, J. G.: Validation of the Harvard Lyman-alpha in situ water vapor instrument: Implications for the mechanisms that control stratospheric water vapor, J. Geophys. Res., 114, D23301, https://doi.org/10.1029/2009jd012427, 2009.

World Meteorological Organization: Scientific Assessment of Ozone Depletion: 2014, Tech. Rep., World Meteorological Organization, Global Ozone Research and Monitoring Project-Report No. 55. Geneva, Switzerland, available at: http://www.esrl.noaa. gov/csd/assessments/ozone/2014/ (last access: 29 September 2021), 2014. 